\title{
Peroxy radical chemistry and the control of ozone photochemistry at Mace Head, Ireland during the summer of 2002
}

\author{
Z. L. Fleming ${ }^{1}$, P. S. Monks ${ }^{1}$, A. R. Rickard ${ }^{1,2}$, D. E. Heard ${ }^{2}$, W. J. Bloss ${ }^{2}$, P. W. Seakins ${ }^{2}$, T. J. Still ${ }^{2}$, R. Sommariva ${ }^{2, *}$, \\ M. J. Pilling ${ }^{2}$, R. Morgan ${ }^{2}$, T. J. Green ${ }^{3}$, N. Brough ${ }^{3}$, G. P. Mills ${ }^{3}$, S. A. Penkett ${ }^{3}$, A. C. Lewis ${ }^{4}$, J. D. Lee , $^{4}$ \\ A. Saiz-Lopez ${ }^{3}$, and J. M. C. Plane ${ }^{3}$ \\ ${ }^{1}$ Department of Chemistry, University of Leicester, Leicester, UK \\ ${ }^{2}$ School of Chemistry, University of Leeds, Leeds, UK \\ ${ }^{3}$ School of Environmental Sciences, University of East Anglia, Norwich, UK \\ ${ }^{4}$ Department of Chemistry, University of York, UK \\ * currently at: Aeronomy Lab, NOAA, USA
}

Received: 12 October 2005 - Published in Atmos. Chem. Phys. Discuss.: 28 November 2005

Revised: 6 March 2006 - Accepted: 6 April 2006 - Published: 20 June 2006

\begin{abstract}
Peroxy radical $\left(\mathrm{HO}_{2}+\Sigma \mathrm{RO}_{2}\right)$ measurements, using the PEroxy Radical Chemical Amplification (PERCA) technique at the North Atlantic Marine Boundary Layer EXperiment (NAMBLEX) at Mace Head in summer 2002, are presented and put into the context of marine, boundarylayer chemistry. A suite of other chemical parameters (NO, $\mathrm{NO}_{2}, \mathrm{NO}_{3}, \mathrm{CO}, \mathrm{CH}_{4}, \mathrm{O}_{3}, \mathrm{VOCs}$, peroxides), photolysis frequencies and meteorological measurements, are used to present a detailed analysis of the role of peroxy radicals in tropospheric oxidation cycles and ozone formation. Under the range of conditions encountered the peroxy radical daily maxima varied from 10 to $40 \mathrm{pptv}$. The diurnal cycles showed an asymmetric shape typically shifted to the afternoon. Using a box model based on the master chemical mechanism the average model measurement agreement was 2.5 across the campaign. The addition of halogen oxides to the model increases the level of model/measurement agreement, apparently by respeciation of $\mathrm{HO}_{\mathrm{x}}$. A good correlation exists between $j(\mathrm{HCHO})$.[HCHO] and the peroxy radicals indicative of the importance of HCHO in the remote atmosphere as a $\mathrm{HO}_{\mathrm{x}}$ source, particularly in the afternoon. The peroxy radicals showed a strong dependence on $\left[\mathrm{NO}_{\mathrm{x}}\right]$ with a break point at $0.1 \mathrm{ppbv}$, where the radicals increased concomitantly with the reactive VOC loading, this is a lower value than seen at representative urban campaigns. The $\mathrm{HO}_{2} /\left(\mathrm{HO}_{2}+\Sigma \mathrm{RO}_{2}\right)$ ratios are dependent on $\left[\mathrm{NO}_{\mathrm{x}}\right]$ ranging between 0.2 and 0.6 , with the ratio increasing linearly with $\mathrm{NO}_{\mathrm{x}}$. Significant night-time levels of peroxy radicals were measured up to $25 \mathrm{pptv}$. The contribution of ozone-alkenes and $\mathrm{NO}_{3}$-alkene chemistry to night-time peroxy radical production was shown to be on average 59 and $41 \%$. The campaign mean net ozone production rate was $0.11 \pm 0.3 \mathrm{ppbv}$
\end{abstract}

Correspondence to: P. S. Monks

(p.s.monks@le.ac.uk) $\mathrm{h}^{-1}$. The ozone production rate was strongly dependent on $[\mathrm{NO}]$ having linear sensitivity $\left(\mathrm{d} \ln \left(\mathrm{P}\left(\mathrm{O}_{3}\right)\right) / \mathrm{d} \ln (\mathrm{NO})=1.0\right)$. The results imply that the $\mathrm{N}\left(\mathrm{O}_{3}\right)$ (the in-situ net photochemical rate of ozone production/destruction) will be strongly sensitive in the marine boundary layer to small changes in [NO] which has ramifications for changing $\mathrm{NO}_{\mathrm{x}}$ loadings in the European continental boundary layer.

\section{Introduction}

Peroxy radicals $\left(\mathrm{HO}_{2}\right.$ and $\mathrm{RO}_{2}$, predominantly $\mathrm{CH}_{3} \mathrm{O}_{2}$ in semi-polluted atmospheres) can be thought of as the intermediates between the hydroxyl $(\mathrm{OH})$ radical and ozone formation or destruction (Monks, 2005). Peroxy radicals also control the removal of primary pollutants such as $\mathrm{NO}_{\mathrm{x}}\left(\mathrm{NO}+\mathrm{NO}_{2}\right)$ and Volatile Organic Compounds (VOCs). Understanding the radical chemistry that controls ozone formation will improve our basic understanding of tropospheric photochemistry and the effect of natural and man-made emissions on ozone formation.

The relative contribution of ozone production and loss processes in the troposphere is highly sensitive to competition between the reaction of peroxy radicals with $\mathrm{NO}$ and their self- and cross-reactions to form peroxides. In the presence of $\mathrm{NO}_{\mathrm{x}}$, the reaction of peroxy radicals with $\mathrm{NO}$ leads to the formation of $\mathrm{NO}_{2}$, which, upon photolysis, forms ozone:

$$
\begin{aligned}
& \mathrm{HO}_{2}+\mathrm{NO} \rightarrow \mathrm{OH}+\mathrm{NO}_{2} \\
& \mathrm{CH}_{3} \mathrm{O}_{2}+\mathrm{NO} \rightarrow \mathrm{CH}_{3} \mathrm{O}+\mathrm{NO}_{2} \\
& \mathrm{CH}_{3} \mathrm{O}+\mathrm{O}_{2} \rightarrow \mathrm{HO}_{2}+\mathrm{HCHO} \\
& \mathrm{NO}_{2}+h v(\lambda<424 \mathrm{~nm}) \rightarrow \mathrm{O}\left({ }^{3} \mathrm{P}\right)+\mathrm{NO} \\
& \mathrm{O}\left({ }^{3} \mathrm{P}\right)+\mathrm{O}_{2}+\mathrm{M} \rightarrow \mathrm{O}_{3}+\mathrm{M}
\end{aligned}
$$

Published by Copernicus GmbH on behalf of the European Geosciences Union. 
In conditions of low $\left[\mathrm{NO}_{\mathrm{x}}\right]$, a catalytic cycle leads to net ozone destruction, shown here for the reaction with $\mathrm{CO}$ :

$$
\begin{aligned}
& \mathrm{HO}_{2}+\mathrm{O}_{3} \rightarrow \mathrm{OH}+2 \mathrm{O}_{2} \\
& \mathrm{OH}+\mathrm{CO} \rightarrow \mathrm{H}+\mathrm{CO}_{2} \\
& \mathrm{H}+\mathrm{O}_{2}+\mathrm{M} \rightarrow \mathrm{HO}_{2}+\mathrm{M} \\
& \text { Overall }: \mathrm{CO}+\mathrm{O}_{3} \rightarrow \mathrm{CO}_{2}+\mathrm{O}_{2}
\end{aligned}
$$

$\mathrm{OH}$ oxidation and other VOCs forms peroxy radicals:

$$
\begin{aligned}
& \mathrm{CH}_{4}+\mathrm{OH} \rightarrow \mathrm{CH}_{3}+\mathrm{H}_{2} \mathrm{O} \\
& \mathrm{CH}_{3}+\mathrm{O}_{2}+\mathrm{M} \rightarrow \mathrm{CH}_{3} \mathrm{O}_{2}+\mathrm{M}
\end{aligned}
$$

Both urban and rural environments are affected by air pollution of photochemical origin, and the modelling of photochemical ozone formation in the British Isles from European emissions are important for the policy-makers in order to develop emission-reduction targets for ozone precursors (Metcalfe et al., 2002, and Derwent et al., 2003). Ozone is one of the major components of photochemical smog, together with contributions from compounds such as carbonyls, peroxy acetyl nitrates (PANs) and various nitrogen oxides. It has been seen in past studies in the relatively clean rural/marine conditions of Mace Head (Salisbury et al., 2001, 2002) during the EASE 96 and 97 (Eastern Atlantic Summer/Spring Experiment) and in the very clean air of Cape Grim in Tasmania (Monks et al., 1998, 2005b) ${ }^{1}$ at the SOAPEX 2 (Southern Ocean Atmospheric Photochemistry EXperiment) campaign in 1998 that ozone formation is part of a natural cycle that can be easily perturbed by pollution events.

Tropical maritime air which is depleted in ozone can be advected to Mace Head over a distance of several thousand kilometres without significant net ozone formation occurring (Derwent et al., 1998). Measurements at Mace Head found that the site experienced more photochemical ozone production than destruction during the EASE 96 and 97 campaigns (Salisbury et al., 2002) and at ATAPEX-95 (Atlantic Atmospheric Photochemistry Experiment) (Carpenter et al., 1997). Cape Grim experienced far more days with net ozone destruction as in SOAPEX 1 in 1995 (Monks et al., 1998, 2000, and Carpenter et al., 1997) and in 1998 at SOAPEX 2 (Monks et al., 2005). Andres-Hernandez et al. (2001) also found that during the Atlantic and Southern Indian Ocean cruise of AEROSOL 99 net ozone destruction predominated.

Penkett et al. (1997) showed that the relationship between the sum of peroxy radicals and the ozone photolysis rate coefficient (to the singlet oxygen atom), $j\left(\mathrm{O}^{1} \mathrm{D}\right)$ can serve as a diagnostic for photochemical ozone production and destruction. In high $\mathrm{NO}_{\mathrm{x}}$ conditions $\mathrm{HO}_{2}+\Sigma \mathrm{RO}_{2}$ is generally proportional to $j\left(\mathrm{O}^{1} \mathrm{D}\right)$ and in clean conditions, to $\sqrt{ } j\left(\mathrm{O}^{1} \mathrm{D}\right)$

\footnotetext{
${ }^{1}$ Monks, P. S., Salisbury, G., and Fleming, Z. L., et al.: The role of peroxy radicals in photochemical destruction of ozone at midlatitudes in the Southern Hemisphere, to be submitted, 2005b.
}

(Penkett et al., 1997; Monks et al., 1998; Zanis et al., 1999; Creasey et al., 2003). The shape of $j\left(\mathrm{O}^{1} \mathrm{D}\right)$ throughout the day produces a typical summer peroxy radical diurnal cycle with maximum values towards solar noon, and minimum values during the night. Photolysis of other photo-labile compounds (e.g. HCHO and HONO) becomes noticeable in the early morning or evening, when the light is of longer wavelengths than those at which ozone photolysis occurs, and can lead to a broader peroxy radical diurnal cycle than that expected from ozone photolysis alone.

In the absence of photochemistry, there is a series of nighttime peroxy radical-producing channels. $\mathrm{NO}_{3}$ (nitrate) radical (Allen et al., 1999; Penkettet al., 1999; Salisbury et al., 2001; Geyer et al., 2003) and ozone reactions with alkenes (Hu and Stedman, 1995; Rickard et al., 1999; Salisbury et al., 2001) were found to be two dominant channels in the marine influenced atmosphere.

In this paper, by use of peroxy radical measurements coupled to a suite of supporting trace species measurements, the photochemical environment of Mace Head is explored. In particular, the shape, concentration and form of the diurnal cycle are explored in relation to both primary production and the potential contribution of the photolysis of secondary compounds such as carbonyls (e.g. HCHO). The dependence of peroxy radical concentration with changing $\mathrm{NO}_{\mathrm{x}}$ and $\mathrm{VOC}$ is described. The role of both $\mathrm{NO}_{3}$ and $\mathrm{O}_{3}$-alkene reactions as night time source of peroxy radicals is investigated. Finally, role of the peroxy radicals in the in situ photochemical formation and destruction of ozone is quantified.

\section{Experimental}

\section{$2.1 \quad$ Site}

NAMBLEX took place from 27 July to 2 September 2002 at the Mace Head Atmospheric Research Station $\left(53^{\circ} 20^{\prime} \mathrm{N}\right.$, $9^{\circ} 54^{\prime} \mathrm{W}$ ). Mace Head is located on the west coast of Ireland, $88 \mathrm{~km}$ west of Galway city, and is in the path of the mid-latitude cyclones which frequently traverse the North Atlantic. Heard et al. (2005) describe the location in more detail, together with the local meteorology of the site, and Norton et al. (2005) provide a detailed analysis of the specific boundary layer conditions encountered during NAMBLEX. The prevailing wind direction is from a westerly marine sector but significant pollution events also reach the site from European continental air-masses, from easterly directions.

\subsection{Peroxy radical measurements (PERCA)}

Measurements of peroxy radicals $\left(\mathrm{HO}_{2}+\Sigma \mathrm{RO}_{2}\right)$ were carried out using the jointly operated University of Leicester University of East Anglia (UEA) PEroxy Radical Chemical 
Amplifier (PERCA IV) instrument, reported for the first time in Green et al. (2005) and Fleming et al. (2006). ${ }^{2}$

The technique was pioneered by Cantrell et al. (1984) and described by Clemitshaw et al. (1997), Monks et al. (1998) and Green et al. (2003) and the current apparatus uses a dual channel inlet and detection system (as in Cantrell et al., 1996).

Briefly, the method relies upon the $\mathrm{HO}_{2}$ and $\mathrm{OH}$ radicalcatalysed conversion of $\mathrm{NO}$ and $\mathrm{CO}$ into $\mathrm{CO}_{2}$ and $\mathrm{NO}_{2}$ respectively, through addition of $\mathrm{NO}$ and $\mathrm{CO}$ into the inlet region viz.,

$$
\begin{aligned}
& \mathrm{HO}_{2}+\mathrm{NO} \rightarrow \mathrm{OH}+\mathrm{NO}_{2} \\
& \mathrm{OH}+\mathrm{CO} \rightarrow \mathrm{H}+\mathrm{CO}_{2} \\
& \mathrm{H}+\mathrm{O}_{2}+\mathrm{M} \rightarrow \mathrm{HO}_{2}+\mathrm{M} \\
& \text { Overall : } \mathrm{NO}+\mathrm{CO}+\mathrm{O}_{2} \rightarrow \mathrm{CO}_{2}+\mathrm{NO}_{2}
\end{aligned}
$$

Organic peroxy radicals are readily converted into $\mathrm{HO}_{2}$ in the presence of $\mathrm{NO}$ with varying efficiencies (Ashbourn et al., 1998). The yield of both $\mathrm{CO}_{2}$ and $\mathrm{NO}_{2}$ is equal to $\mathrm{CL} *\left(\left[\sum \mathrm{RO}_{2}\right]+\left[\mathrm{HO}_{2}\right]+[\mathrm{OH}]\right)$, where $\mathrm{CL}$ is the chain length, i.e. the number of $\mathrm{HO}_{2} / \mathrm{OH}$ inter-conversion cycles that occur before radical termination. The ratio of $\left[\mathrm{HO}_{2}\right] /[\mathrm{OH}]$ ranges from 50-200 in the atmosphere, therefore the PERCA technique effectively measures the sum of inorganic and organic peroxy radicals. The yield of $\mathrm{NO}_{2}$ is measured using commercial LMA-3 detectors (calibrated daily using $\mathrm{NO}_{2}$ permeation sources) and this is converted into $\left[\mathrm{HO}_{2}+\Sigma \mathrm{RO}_{2}\right]$ using $\Delta\left[\mathrm{NO}_{2}\right] / \mathrm{CL}$. The chain length was calculated on a weekly basis, using a calibration source based upon the photolysis of $\mathrm{CH}_{3} \mathrm{I}$ at $253.7 \mathrm{~nm}$ to yield $\mathrm{CH}_{3} \mathrm{O}_{2}$ at varying concentrations (Clemitshaw et al., 1997).

Background $\left[\mathrm{NO}_{2}\right]$ signals (caused by the reaction of ambient ozone with NO in the inlet) were measured by changing the addition points of the reagent gases, so that the amplification reactions are not initiated. The overall radical levels are calculated by subtracting the termination signal from the amplification signal.

The dual-inlet system comprises two distinct sampling systems, inlet reaction sites and detectors. The advantage of this dual-inlet system is that the two systems are run out of phase in two modes, with one in amplification and the other in termination mode. Switching the two inlets between phases on a minute time scale leads to a continuous amplification and termination signal.

Mihele et al. $(1998,1999)$ have shown that the chain length of a chemical amplifier is reduced in the presence of atmo-

\footnotetext{
${ }^{2}$ Fleming, Z. L., Monks, P. S., Rickard, A. R., Bandy, B. J., Brough, N., Green, T. J., Reeves, C. E., and Penkett, S. A.: Seasonal dependence of peroxy radical concentrations at a Northern hemisphere marine boundary layer site during summer and winter: Evidence for photochemical activity in winter, Atmos. Chem. Phys. Discuss., submitted, 2006.
}

spheric water vapour (see also Reichert et al., 2003). Salisbury et al. (2002) demonstrated that the chain length of the Leicester-UEA PERCA instrument falls approximately linearly with increasing specific humidity. From a series of laboratory experiments, a humidity correction factor equation (using ambient humidity and inlet temperatures) was derived and applied to all PERCA data. In order to minimise the applied correction factor, the inlet temperature was kept above ambient temperatures at the constant value of $30^{\circ} \mathrm{C}$. The humidity correction factor varied between 1.5 and 2.5 during NAMBLEX. (see also Fleming et al., 2006).

The accuracy and precision of the dual-inlet PERCA have been assessed in detail by Fleming (2006). The overall uncertainty for any given peroxy radical measurement is $38 \%$ (at $1 \sigma)$ from a combination of uncertainties associated with the radical calibration, $\mathrm{NO}_{2}$ quantification and humidity correction. The precision on a 1 pptv measurement averaged over a minute assessed from the reproducibility of the radical calibration was $15 \%$. The detection limit of the instrument was of the order of $0.5 \mathrm{pptv}$ at a $\mathrm{S} / \mathrm{N}$ of 1 on a $1 \mathrm{~min}$ average.

The PERCA instrument inlet box was securely attached $6 \mathrm{~m}$ above ground level to a tower on a temporary laboratory building (sea container) close to the main shoreline site and an umbilical line carried the reagent gases and sample lines down to the main rack in the laboratory (see Heard et al., 2005, for a site plan). The PERCA instrument took measurements continuously during the campaign in minute averages and analysis was carried out with ten minute- or hourlyaveraged data.

\subsection{Other measurements}

Meteorological data were obtained from the site's fixed meteorological station, which recorded ambient air temperature, relative humidity, wind speed and wind direction. The other instruments were housed in the permanent cottages of the site or in similar self-contained temporary buildings (seacontainers). Details of the instruments, their detection limits and accuracy are given in Heard et al. (2005).

\subsection{Modelling studies}

The Master Chemical Mechanism (currently MCMv3.1, available online at http://mcm.leeds.ac.uk/MCM/) Developed by Jenkin et al. (1997) and subsequently refined and updated by Saunders et al. (2003); Jenkin et al. (2003) and Bloss et al. (2005a, b) MCMv3.1 contains the oxidation mechanisms of 135 primary emitted VOCs. This mechanism was added to a campaign optimised box model used to simulate $\mathrm{HO}_{2}, \mathrm{RO}_{2}$ and $\mathrm{OH}$ radical concentrations constrained with $\mathrm{H}_{2}, \mathrm{CO}, \mathrm{CH}_{4}, \mathrm{O}_{3}, \mathrm{NO}, \mathrm{NO}_{2}, \mathrm{HCHO}$, measured VOCs, chloroform, temperature and various photolysis rates measurements. In general, the most complete model shown in this analysis is termed "full-oxy" and is detailed extensively in Sommariva et al. (2006a). In addition, the model was then 
Table 1. Campaign air-mass sector-averaged chemical and physical parameters ( $\sigma \sigma$ standard deviation given in brackets.)

\begin{tabular}{llllllll}
\hline & $\mathrm{NW}$ & $\mathrm{N}$ & $\mathrm{SW}$ & $\mathrm{W}$ & $\mathrm{S}$ & $\mathrm{NE}$ & $\mathrm{E}$ \\
\hline $\mathrm{HO}_{2}+\sum \mathrm{RO}_{2} / \mathrm{pptv}$ & $7.6(6)$ & $7.9(4)$ & $7.1(6)$ & $10.2(8)$ & $13.7(10)$ & $13.4(10)$ & $13.5(7)$ \\
$\mathrm{NO}_{\mathrm{x}} / \mathrm{pptv}$ & $151(39)$ & $73(68)$ & $111(136)$ & $63(33)$ & $230(418)$ & $275(212)$ & $352(72)$ \\
$\mathrm{NO} / \mathrm{pptv}$ & $19(47)$ & $10(14)$ & $13(12)$ & $10(7)$ & $24(55)$ & $31(21)$ & $34(26)$ \\
$\mathrm{CH}_{4} / \mathrm{ppbv}$ & $1813(20)$ & $1816(32)$ & $1785(30)$ & $1800(13)$ & $1821(30)$ & $1863(50)$ & $1925(29)$ \\
$\mathrm{CO} / \mathrm{ppbv}$ & $90(12)$ & $81(3)$ & $77(14)$ & $83(6)$ & $82(5)$ & $112(18)$ & $149(10)$ \\
$\mathrm{O}_{3} / \mathrm{ppbv}$ & $33(4)$ & $29(4)$ & $25(7)$ & $24(12)$ & $23(12)$ & $32(4)$ & $39(2)$ \\
$\mathrm{H}_{2} \mathrm{O}_{2} / \mathrm{pptv}$ & $0.19(0.19)$ & $0.21(0.14)$ & $0.09(0.07)$ & $0.20(0.10)$ & $0.14(0.05)$ & $0.18(0.11)$ & $0.37(0.10)$ \\
$\mathrm{HCHO} / \mathrm{ppbv}$ & $1.38(0.18)$ & $1.20(0.08)$ & $1.22(0.17)$ & $1.28(0.26)$ & $1.34(0.12)$ & $1.62(0.22)$ & $2.09(0.17)$ \\
$\mathrm{DMS} / \mathrm{pptv}$ & $120(98)$ & $233(66)$ & $388(264)$ & $244(227)$ & $100(107)$ & $131(88)$ & $23(24)$ \\
Isoprene /pptv & $13(24)$ & $4(1)$ & $2(1)$ & $5(6)$ & $30(61)$ & $72(119)$ & $15(26)$ \\
Benzene /pptv & $29(14)$ & $24(17)$ & $20(4)$ & $27(17)$ & $18(7)$ & $62(22)$ & $114(11)$ \\
Methanol /pptv & $1068(365)$ & $852(233)$ & $1536(384)$ & $1086(370)$ & $1204(291)$ & $1747(630)$ & $1559(596)$ \\
\hline
\end{tabular}

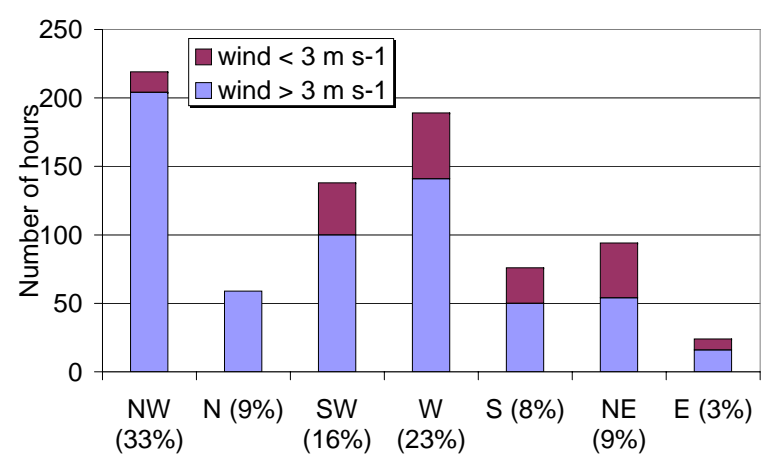

Fig. 1. Air-mass sector divisions for winds less than and greater than $3 \mathrm{~ms}^{-1}$.

also constrained with 23 hydrocarbons, 3 oxygenates and 2 peroxides and to temperature and photolysis measurements. $\mathrm{OH}$ and $\mathrm{HO}_{2}$ model/measurement comparisons are reported in Smith et al. (2006), Sommariva et al. (2006a) and nighttime $\mathrm{HO}_{2}$ and $\mathrm{RO}_{2}$ in Sommariva et al. (2006b). Model results at NAMBLEX for $\mathrm{HO}_{2}$ were in much better agreement with the measurements when the model was additionally constrained to measured halogen oxides (Sommariva et al., 2006a; Bloss et al., 2005c).

\section{Results}

\subsection{Meteorological conditions and chemical climatology}

Local wind speed and direction measurements were recorded on an hourly basis during NAMBLEX. During the EASE campaigns Salisbury et al. (2002), and Rickard et al. (2002) divided all the data into five sectors, according to local wind direction.
More detailed boundary layer structure measurements in combination with back trajectory analysis during the NAMBLEX campaign is described by Norton et al. (2005). However, caution must be used when assigning air-mass sectors only according to local in-situ wind direction as measurements during the NAMBLEX data did not necessarily correspond with the origin of the air-mass back-trajectory analysis. For example, there were a number of land-sea breeze events (particularly at night). From 1 to 5 August, these breeze events brought local easterly winds to the site during westerly trajectories.

The British Atmospheric Data Centre's (BADC) trajectory service (http//:www.badc.nerc.ac.uk) was used to plot fiveday air-mass back-trajectories at six-hourly intervals. According to the origin of the air-masses of these trajectories, a new division into seven areas of origin was developed as shown in Tables 1,2 and 3. The most common air-mass sector was the north-westerly (NW), followed by westerly (W) and then south-westerly (SW) as shown in Fig. 1 (see also Heard et al., 2005). The effects of local sea and coastal breezes were removed from the analysis by only selecting data where the local wind speed was greater than $3 \mathrm{~m} \mathrm{~s}^{-1}$ (Salisbury et al., 2002).

Table 1 shows the average $\mathrm{HO}_{2}+\Sigma \mathrm{RO}_{2}, \mathrm{NO}_{\mathrm{x}}, \mathrm{CO}, \mathrm{CH}_{4}$, $\mathrm{O}_{3}, \mathrm{CH}_{3} \mathrm{OOH}, \mathrm{H}_{2} \mathrm{O}_{2}, \mathrm{HCHO}$, DMS, isoprene, benzene and methanol mixing ratios and $j\left(\mathrm{O}^{1} \mathrm{D}\right)$ for the corresponding air-mass sectors. The data in Table 2 corresponds to the daylight (06:00-19:00) averages. Table 3 shows the night-time concentrations of the same species, as well as $\left[\mathrm{NO}_{3}\right]$ and total alkenes.

Heard et al. (2005) provides a comprehensive overview of all the other species and supporting measurements made during NAMBLEX and their respective time series. 
Table 2. Daylight-only (06:00 to 19:00 UT) air-mass sector-averaged chemical and physical parameters ( $\sigma \sigma$ standard deviation given in brackets.)

\begin{tabular}{llllllll}
\hline & $\mathrm{NW}$ & $\mathrm{N}$ & $\mathrm{SW}$ & $\mathrm{W}$ & $\mathrm{S}$ & $\mathrm{NE}$ & $\mathrm{E}$ \\
\hline $\mathrm{HO}_{2}+\sum \mathrm{RO}_{2} / \mathrm{pptv}$ & $10.6(6)$ & $9.6(5)$ & $8.5(7)$ & $15.1(9)$ & $16.4(11)$ & $21.0(9)$ & $17.4(9)$ \\
$\mathrm{NO}_{\mathrm{x}} / \mathrm{pptv}$ & $133(256)$ & $88(77)$ & $80(39)$ & $65(30)$ & $190(497)$ & $216(112)$ & $342(93)$ \\
$\mathrm{NO} / \mathrm{pptv}$ & $31(61)$ & $16(17)$ & $15(11)$ & $13(7)$ & $34(66)$ & $43(20)$ & $57(21)$ \\
$\mathrm{CH}_{4} / \mathrm{ppbv}$ & $1814(22)$ & $1818(36)$ & $1783(30)$ & $1799(13)$ & $1817(29)$ & $1852(44)$ & $1904(29)$ \\
$\mathrm{CO} / \mathrm{ppbv}$ & $90(12)$ & $80(3)$ & $76(15)$ & $83(5)$ & $82(5)$ & $111(18)$ & $143(8)$ \\
$\mathrm{O}_{3} / \mathrm{ppbv}$ & $33(4)$ & $28(4)$ & $25(7)$ & $26(12)$ & $20(14)$ & $33(4)$ & $39(3)$ \\
$j\left(\mathrm{O}^{1} \mathrm{D}\right) \times 10^{-6} / \mathrm{s}^{-1}$ & $7.8(7)$ & $6.9(6)$ & $5.9(6)$ & $7.2(5)$ & $8.5(6)$ & $8.1(6)$ & $7.3(8)$ \\
$\mathrm{N}\left(\mathrm{O}_{3}\right) / \mathrm{ppbv} \mathrm{h}$ & $0.023(0.2)$ & $0.028(0.1)$ & $-0.019(0.08)$ & $0.025(0.2)$ & $0.087(0.3)$ & $0.51(0.5)$ & $0.47(0.3)$ \\
$\mathrm{H}_{2} \mathrm{O}_{2} / \mathrm{pptv}$ & $0.20(0.2)$ & $0.17(0.1)$ & $0.08(0.1)$ & $0.22(0.1)$ & $0.14(0.04)$ & $0.17(0.1)$ & $0.41(0.08)$ \\
$\mathrm{HCHO} / \mathrm{ppbv}$ & $1.5(0.2)$ & $1.2(0.1)$ & $1.2(0.1)$ & $1.4(0.3)$ & $1.4(0.2)$ & $1.7(0.2)$ & $2.1(0.2)$ \\
\hline
\end{tabular}

Table 3. Night-time-only (19:00-06:00) air-mass sector-averaged chemical and physical parameters ( $\sigma \sigma$ standard deviation given in brackets.)

\begin{tabular}{|c|c|c|c|c|c|c|c|}
\hline & NW & $\mathrm{N}$ & SW & $\mathrm{W}$ & $\mathrm{S}$ & $\mathrm{NE}$ & $\mathrm{E}$ \\
\hline $\mathrm{HO}_{2}+\sum \mathrm{RO}_{2} / \mathrm{pptv}$ & $4.2(2)$ & $5.6(1)$ & $4.4(3)$ & $4.1(2)$ & $6.4(5)$ & $7.7(2)$ & $10.5(3)$ \\
\hline $\mathrm{NO}_{\mathrm{x}} / \mathrm{pptv}$ & $174(521)$ & $59(57)$ & $152(200)$ & $61(36)$ & $301(214)$ & $344(274)$ & $359(54)$ \\
\hline $\mathrm{NO} / \mathrm{pptv}$ & $4.8(3)$ & $4.7(4)$ & $9.6(13)$ & $6.1(6)$ & $4.9(3)$ & $17.0(12)$ & $15.2(8)$ \\
\hline $\mathrm{CH}_{4} / \mathrm{ppbv}$ & $1813(17)$ & $1814(28)$ & $1787(31)$ & $1802(14)$ & $1827(33)$ & $1877(53)$ & $1941(16)$ \\
\hline $\mathrm{CO} / \mathrm{ppbv}$ & $90(13)$ & $81(2)$ & $78(12)$ & $84(6)$ & $81(3)$ & $113(19)$ & 154 (11) \\
\hline $\mathrm{O}_{3} / \mathrm{ppbv}$ & $32(4)$ & $30(2)$ & $26(8)$ & $22(12)$ & $28(6)$ & $31(3)$ & $40(2)$ \\
\hline $\mathrm{NO}_{3} / \mathrm{pptv}$ & $4.7(2)$ & $5.9(3)$ & nd & $4.5(2)$ & $2.7(1)$ & $5.7(5)$ & $11.7(6)$ \\
\hline $\mathrm{HCHO} / \mathrm{ppbv}$ & $1.28(0.16)$ & $1.16(0.05)$ & $1.25(0.23)$ & $1.14(0.17)$ & $1.33(0.07)$ & $1.54(0.23)$ & nd \\
\hline Alkenes /pptv & $60(48)$ & $33(11)$ & $71(57)$ & $64(30)$ & $71(47)$ & $187(141)$ & $188(82)$ \\
\hline
\end{tabular}

nd: No Data

\subsubsection{Peroxy radical levels and diurnal cycles}

The data in Table 1 and the peroxy radical time series in Fig. 2 show that peroxy radical concentrations are highest when the air is of continental origin ( $\mathrm{S}, \mathrm{E}$ and $\mathrm{NE}$ airmass sectors). Also the concentrations of $\mathrm{NO}_{\mathrm{x}}$, isoprene and formaldehyde were significantly higher in these sectors than in the marine $\mathrm{W}$ sector.

The lowest peroxy radical concentrations during the campaign were near the detection limit of the instrument (see experimental section) at around 1 pptv but were rarely less than 4 pptv, even at night. The maximum peroxy radical concentration reached $60 \mathrm{pptv}$ for the occasional short-lived spike and 40 pptv for midday maximum values (see Fig. 2). Generally, the average day-time peroxy radical concentrations were between two and three times higher than night-time levels.

The campaign average $\left[\mathrm{HO}_{2}+\Sigma \mathrm{RO}_{2}\right],\left[\mathrm{NO}_{\mathrm{x}}\right]$ and $j\left(\mathrm{O}^{1} \mathrm{D}\right)$ diurnal cycles and the $\mathrm{W}$ and $\mathrm{NE}$ air-mass sector-averaged diurnal cycles are shown in Fig. 3. Peroxy radicals track the $j\left(\mathrm{O}^{1} \mathrm{D}\right)$ diurnal cycle fairly closely, with the cycle being shifted towards the end of the day as high midday concentrations persist well into the afternoon. This form of asymmetrical diurnal cycle has been noted before in low- $\mathrm{NO}_{\mathrm{x}}$ environments by Monks et al. (1996) at Cape Grim, Carpenter et al. (1997) at Mace Head in 1995, and in high $\mathrm{NO}_{\mathrm{x}}$ environments by Holland et al. (2003) and Mihelcic et al. (2003) at the BERLIOZ campaign near Berlin. In each of these environments there are different mechanisms that drive this asymmetry. The peroxy radical diurnal cycle for the $\mathrm{W}$ airmass sector has less relative variability, tracking $j\left(\mathrm{O}^{1} \mathrm{D}\right)$ with a slight bias in maxima towards the afternoon. The NE sector peroxy radical diurnal is broader in both the morning and the evening. The $\mathrm{S}$ sector diurnal cycle (not shown) follows a similar pattern to the NE average in that it has a broader shape in both the morning and the afternoon. 


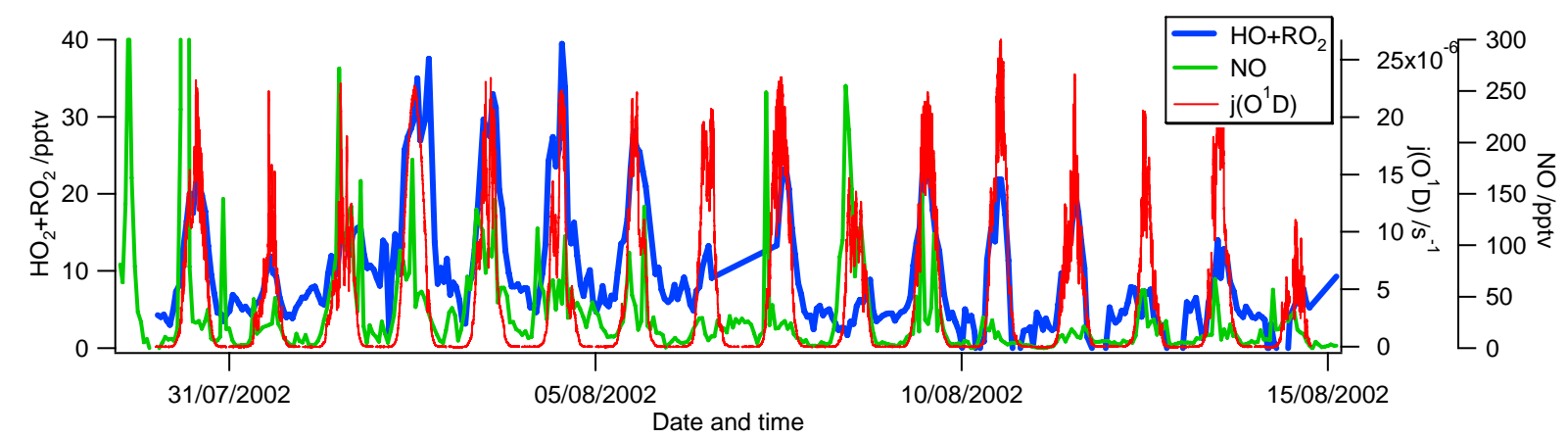

Fig 2

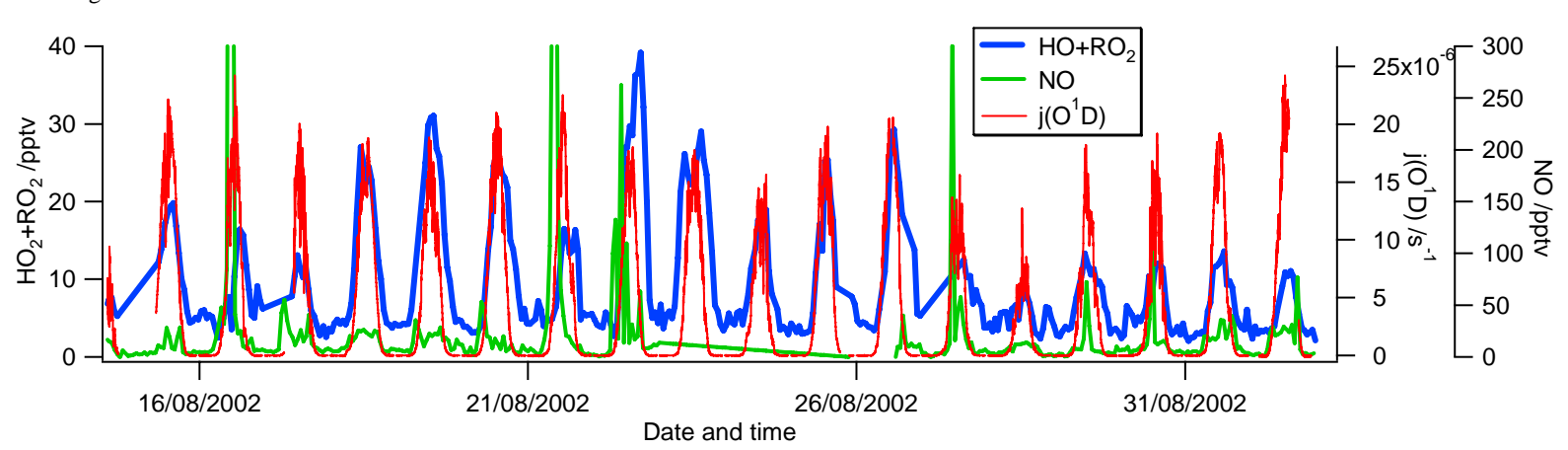

Fig. 2. $\left[\mathrm{HO}_{2}+\Sigma \mathrm{RO}_{2}\right], j\left(\mathrm{O}^{1} \mathrm{D}\right)$ and $[\mathrm{NO}]$ campaign time series.

Table 4. Sensitivity of the Model/Measurement $\mathrm{HO}_{2}+\Sigma \mathrm{RO}_{2}$ agreement for varying chemical complexity.

\begin{tabular}{|c|c|}
\hline Model Run ${ }^{\mathrm{a}}$ & Model/Measurement \\
\hline $\begin{array}{l}\mathrm{CO}+\mathrm{CH}_{4} \text { chemistry (Het with IO chemistry) } \\
- \text { constrained to measurements of } \mathrm{CO} \text { and } \mathrm{CH}_{4}\end{array}$ & $3.3 \pm 1.8$ \\
\hline $\begin{array}{l}\text { Full Chemistry (Het with IO chemistry) } \\
\text { - constrained to measurements of } \mathrm{CO}, \mathrm{CH}_{4}, 23 \text { hydrocarbons and chloroform }\end{array}$ & $2.6 \pm 1.3$ \\
\hline $\begin{array}{l}\text { Full }+ \text { Oxy } \\
\text { - constrained to measurements of } \mathrm{CO}, \mathrm{CH}_{4}, 23 \text { hydrocarbons, chloroform } \\
\text { and } 3 \text { oxygenates }\end{array}$ & $2.5 \pm 1.3$ \\
\hline $\begin{array}{l}\text { Full }+ \text { Oxy (Het with IO chemistry) } \\
\text { - constrained to measurements of } \mathrm{CO}, \mathrm{CH}_{4}, 23 \text { hydrocarbons, chloroform } \\
\text { and } 3 \text { oxygenates }\end{array}$ & $2.3_{41} \pm 1.2$ \\
\hline $\begin{array}{l}\text { Full }+\mathrm{Oxy}+\mathrm{Per}(\text { Het with } \mathrm{IO} \text { chemistry) } \\
- \text { constrained to measurements of } \mathrm{CO}, \mathrm{CH}_{4}, 23 \text { hydrocarbons, chloroform, } 3 \\
\text { oxygenates and } 2 \text { peroxides }\end{array}$ & $2.3_{43} \pm 1.2$ \\
\hline
\end{tabular}

a: Full details of model runs in Sommariva et al. (2006); Het with IO chemistry-model additionally constrained to measured IO and $j$ (HOI) using a transition regime expression to calculate the heterogeneous uptake of the gas-phase species.

An extensive modelling study by Sommariva et al. (2006a) has investigated the impact of oxygenate and halogen chemistry on the radical chemistry. Table 4 shows the sensitivity of the average model/measurement agreement for $\mathrm{HO}_{2}+\Sigma \mathrm{RO}_{2}$ with varying model assumptions. Figure 4 a shows the results using the full oxygenate chemistry constrained to measured
IO with corrected heterogeneous uptake model and measured peroxy radical concentrations for 15-22 August, and the same model run with the measured $\mathrm{HO}_{2}$ from the FAGE instrument (Smith et al., 2006). For the model run with full oxygenate chemistry constrained to measured IO with corrected heterogeneous uptake (see Table 4), the peroxy radi- 

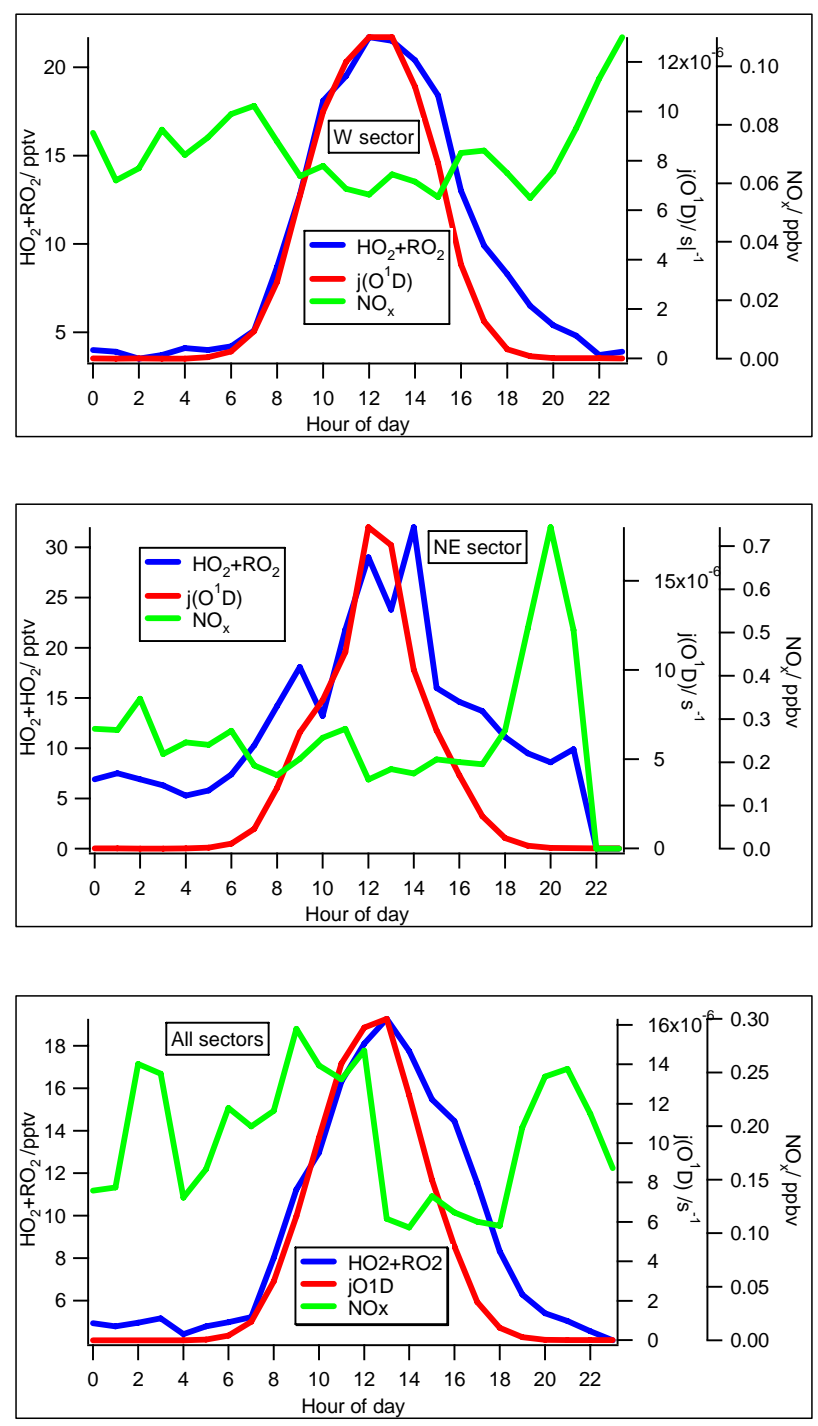

Fig. 3. Hourly-averaged $\left[\mathrm{HO}_{2}+\Sigma \mathrm{RO}_{2}\right]$, $\left[\mathrm{NO}_{\mathrm{x}}\right]$ and $j\left(\mathrm{O}^{1} \mathrm{D}\right)$ diurnal cycles for all campaign data and $\mathrm{W}$ and $\mathrm{NE}$ air-mass sector data subsets.

cal measurement-model agreement is within the uncertainty of both the model and measurements. In general, the radical measurements are slightly higher than the model during the day-time. However, the model $\mathrm{HO}_{2}$ constantly over-predicts the measured $\mathrm{HO}_{2}$ concentrations, by at least a factor of 2-3 (Sommariva et al., 2006a). Inclusion of the halogen chemistry, in terms of measured IO seems to give some small improvement in the agreement. It is worth noting that there is some evidence for spatial in homogeneity in the $[\mathrm{IO}]$ and the "local" [IO] could be a factor or 10 higher than that measured by long-path DOAS methods (see Sommariva et al., 2006a, and Smith et al., 2006). The effect of halogens on the partitioning of $\mathrm{NO}$ and $\mathrm{NO}_{2}$ and $\mathrm{OH}$ and $\mathrm{HO}_{2}$ is dealt with later. Figure $4 \mathrm{~b}$ shows a correlation plot of modelled PERCA peroxy radical (full + oxy, heterogeneous with IO chemistry, see
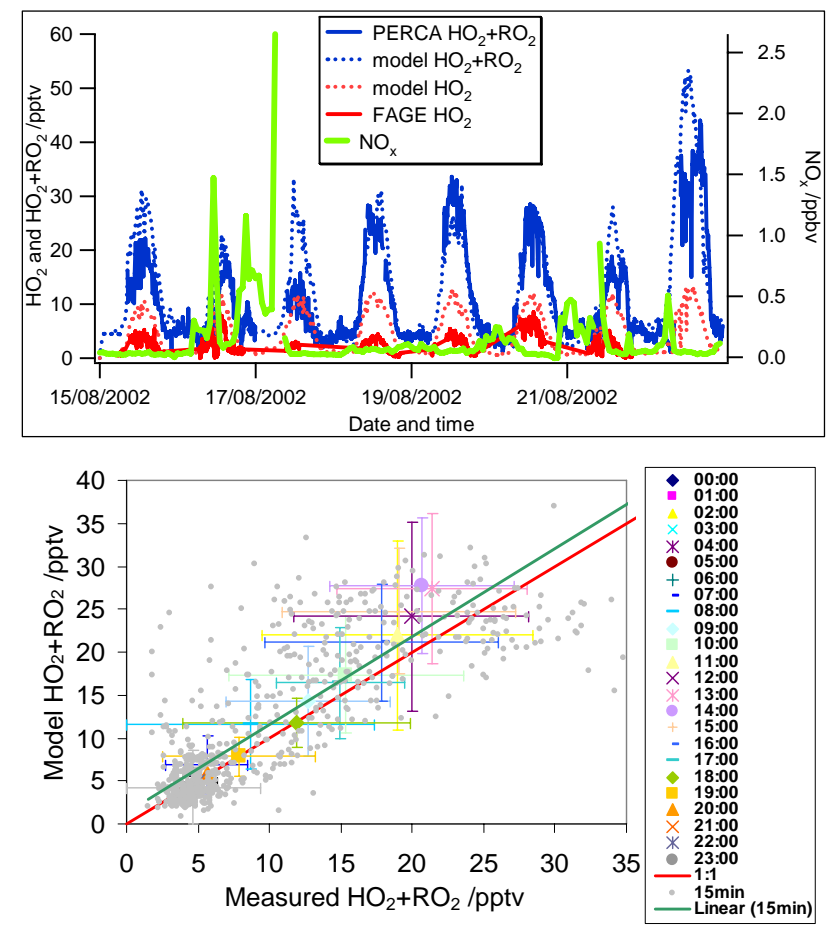

Fig. 4. (a) Measured and modelled PERCA $\left[\mathrm{HO}_{2}+\sum \mathrm{RO}_{2}\right]$ and FAGE $\left[\mathrm{HO}_{2}\right]$; (b) MCM modelled vs. measured $\left[\mathrm{HO}_{2}+\sum \mathrm{RO}_{2}\right]$ (15 min data) and hourly-averaged data.

Table 4) concentrations against measured values for all fifteen minute-averaged data and also the hourly-averages with their corresponding standard deviation. From Fig. 4b, there is a good correlation with the slope $=1.0_{2}\left(\mathrm{R}^{2}=0.73\right)$. At low $\left[\mathrm{HO}_{2}+\sum \mathrm{RO}_{2}\right]$, the model-measurement comparison lies below the 1:1 line. At higher $\left[\mathrm{HO}_{2}+\sum \mathrm{RO}_{2}\right]$, there is a wider spread of data and the model, particularly for the hourly averages around solar noon over-predicts the measured peroxy radical levels.

Correlations of $j\left(\mathrm{O}^{1} \mathrm{D}\right), \sqrt{ } j\left(\mathrm{O}^{1} \mathrm{D}\right)$ vs. $\left[\mathrm{HO}_{2}+\Sigma \mathrm{RO}_{2}\right]$ and diurnal cycles for 23 and 24 August are shown in Fig. 5. The back trajectories shown in Fig. 5 suggest a SW air-mass origin on 23 August coming off the French coast, bringing higher concentrations of $\mathrm{CO}, \mathrm{CH}_{4}$, acetone, methanol and $\mathrm{NO}_{\mathrm{x}}$. The following day, the air-mass changes to a cleaner $\mathrm{NW}$ origin, where the $\mathrm{NO} / \mathrm{NO}_{\mathrm{x}}$ ratio and [NMHC] are significantly lower. The narrower shape of the diurnal cycle on 24 August could be due to a reduction in species that could be photolysed to form peroxy radicals.

On the NW day (24 August), peroxy radicals track $j\left(\mathrm{O}^{1} \mathrm{D}\right)$, whereas on the SW day (23 August), the peroxy radicals have a broader shape than $j\left(\mathrm{O}^{1} \mathrm{D}\right)$. The correlation with both $j\left(\mathrm{O}^{1} \mathrm{D}\right)$ and $\sqrt{ } j\left(\mathrm{O}^{1} \mathrm{D}\right)\left(\mathrm{r}^{2}=0.87\right.$ and 0.89 respectively) is good on the NW day but poor $\left(r^{2}=0.30\right.$ and 0.43$)$ on the SW day. Since the correlation with $j\left(\mathrm{O}^{1} \mathrm{D}\right)$ on the SW day is poor, this is suggestive of an increased secondary 


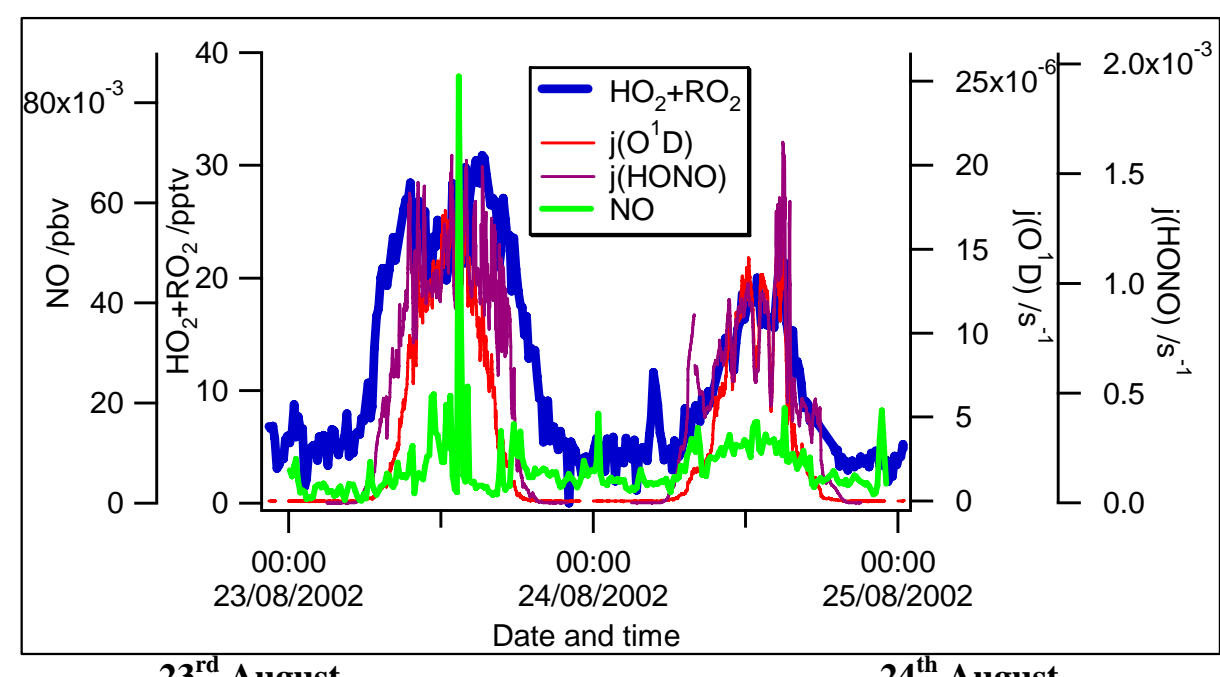

$23^{\text {rd }}$ August
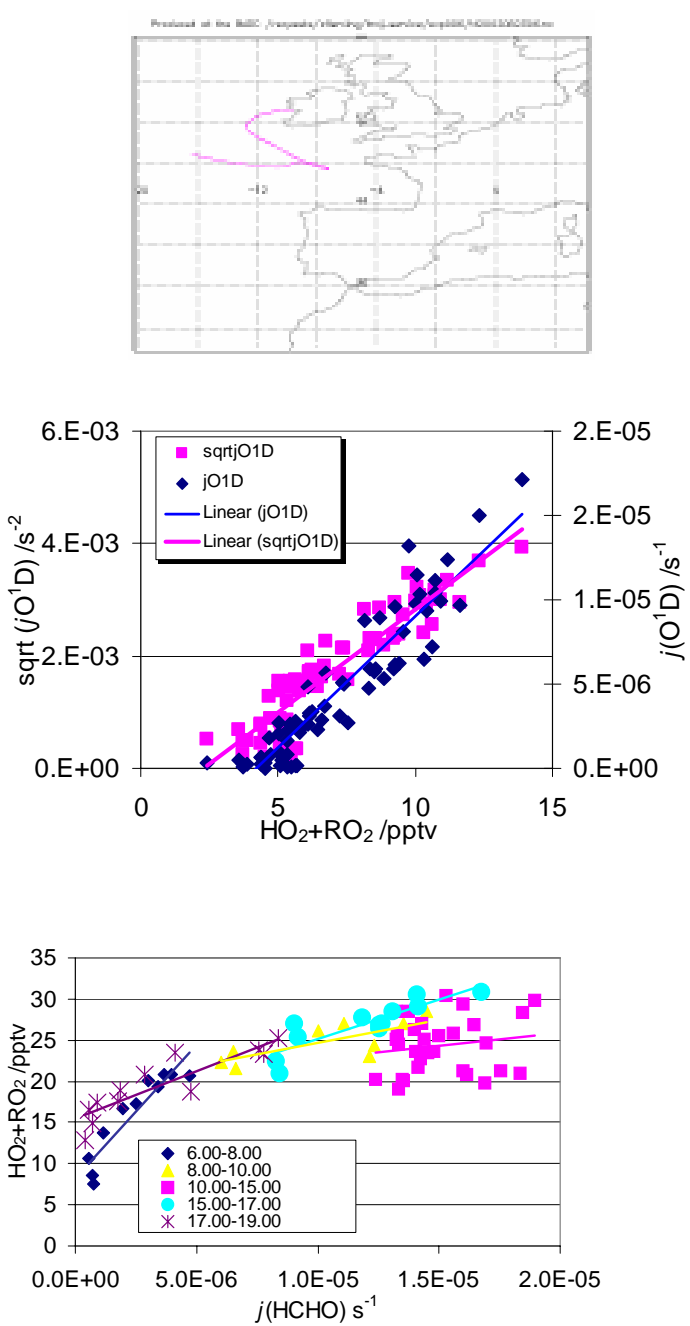

$24^{\text {th }}$ August
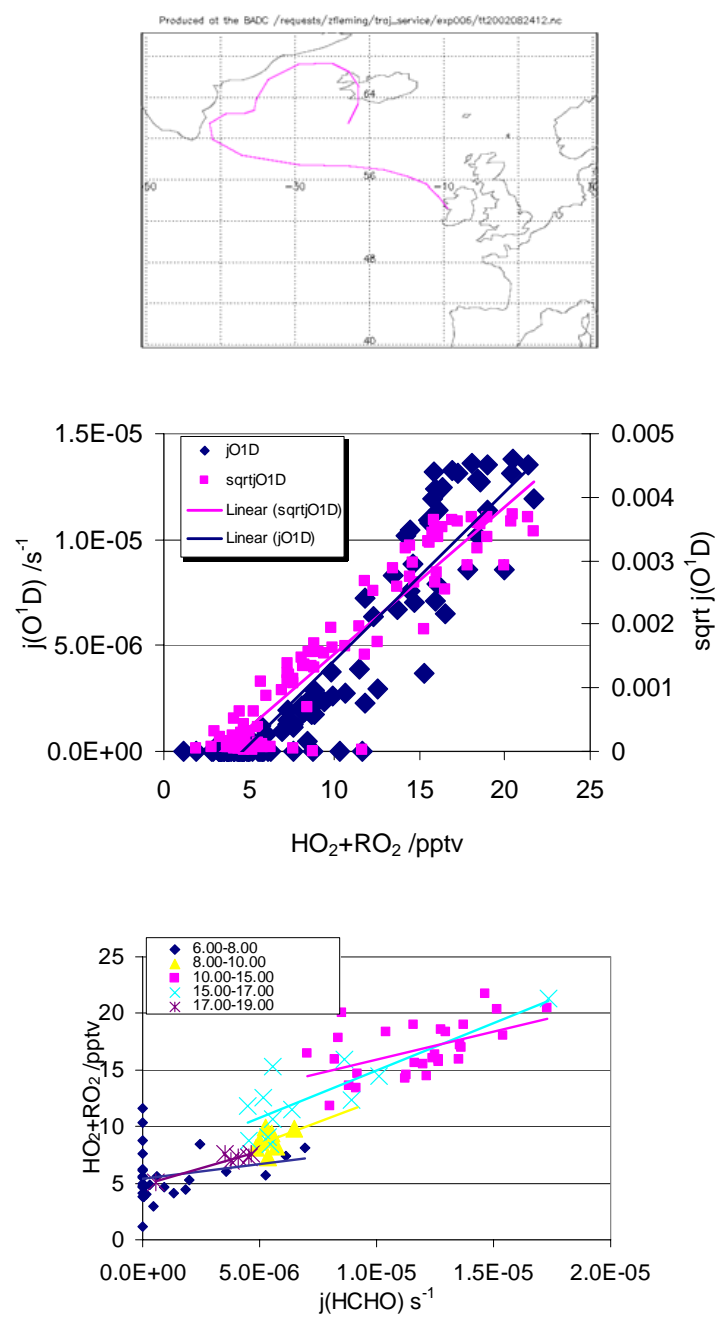

Fig. 5. Data for 23 and 24 August, $\mathrm{HO}_{2}+\sum \mathrm{RO}_{2}$ and $j\left(\mathrm{O}^{1} \mathrm{D}\right)$ diurnal cycles and five-day back-trajectories. $j\left(\mathrm{O}^{1} \mathrm{D}\right)$ and $\sqrt{ } j\left(\mathrm{O}^{1} \mathrm{D}\right)$ vs. $\left[\mathrm{HO}_{2}+\sum \mathrm{RO}_{2}\right]$ linear regressions and $\left[\mathrm{HO}_{2}+\sum \mathrm{RO}_{2}\right]$ vs. $j(\mathrm{HCHO})_{\text {rad }}$ trends at different periods of the day are shown beneath the back-trajectories. The average concentrations/rates on 23 and 24 August where $\mathrm{NO}=6.3 \pm 8.3,7.3 \pm 3.9 \mathrm{pptv}, \mathrm{HO}_{2}+\sum \mathrm{RO}_{2}=14.7 \pm 9.4$, $8.3 \pm 5.4 \mathrm{pptv}, j\left(\mathrm{O}^{1} \mathrm{D}\right)_{\mathrm{day}}=7.3 \times 10^{-6} \pm 5.7 \times 10^{-6}, 5.5 \times 10^{-6} \pm 4.8 \times 10^{-6} \mathrm{~s}^{-1}$. 
source of $\mathrm{HO}_{\mathrm{x}}$ from the photolysis of other compounds. This is particularly apparent in the early morning and the evening.

Photolysis of species other than $\mathrm{O}_{3}$ (e.g. $\mathrm{HCHO}, \mathrm{HONO}$, $\mathrm{H}_{2} \mathrm{O}_{2}, \mathrm{CH}_{3} \mathrm{O}_{2} \mathrm{H}$ ) could lead to a broadening of the peroxy radical diurnal cycle noted in the afternoon or early morning, when $j\left(\mathrm{O}^{1} \mathrm{D}\right)$ (primary production) is reduced. $\left[\mathrm{HO}_{2}+\sum \mathrm{RO}_{2}\right]$ vs. $j(\mathrm{HCHO})$ correlations are divided into five different periods of the day in Fig. 5 (23 August, $\mathrm{r}^{2}(6-$ 8) $0.87,(8-10) 0.57,(10-15) 0.03,(15-17) 0.75,(17-19)$ 0.79 ; 24th August, $\mathrm{r}^{2}(6-8) 0.05,(8-10) 0.18,(10-15) 0.28$, (15-17) 0.70, (17-19) 0.90). On the 23 August, the largest increase in peroxy radicals as $j(\mathrm{HCHO})$ increases was seen at 06:00-08:00 and 15:00-17:00 UT. Despite the large increase in peroxy radicals with increasing $j(\mathrm{HCHO})$ between 06:00 and 08:00, the $j(\mathrm{HCHO})$ values were very low and would not have led to significant peroxy radical formation from this channel alone. Between 17:00-19:00 UT the product $(j(\mathrm{HCHO})$.[HCHO] $)$ was significantly large as to produce peroxy radicals at this time when $j\left(\mathrm{O}^{1} \mathrm{D}\right)$ was greatly reduced. 24 August showed very poor trends. The same form of analysis with $j(\mathrm{HONO})$ showed no observable trends (N.B. [HONO] estimated).

Figure $6 \mathrm{a}$ shows the campaign averaged [HCHO] and $\left[\mathrm{HO}_{2}+\sum \mathrm{RO}_{2}\right]$ diurnal cycles and the amount of $\mathrm{HCHO}$ photolysed each $\mathrm{h}(\mathrm{j}(\mathrm{HCHO})$.[HCHO]). Formaldehyde has a shifted diurnal cycle with values persisting into the evening. Daily maximum [HCHO] were around $1.6 \mathrm{ppbv}$ (Still et al., 2005), much higher than the $0.2-0.8 \mathrm{ppbv}$ found during a comparable campaign at Mace Head (Cardenas et al., 2000). The relative performance of the different HCHO measurement methods are discussed in Still et al. (2005).

Figure $6 \mathrm{~b}$ shows correlation plots of $\left[\mathrm{HO}_{2}+\sum \mathrm{RO}_{2}\right]$ and [HCHO] against the amount of formaldehyde photolysed per hour $(j(\mathrm{HCHO} .[\mathrm{HCHO}])$. Both peroxy radicals and formaldeyde show a good correlation with formaldehyde photolysis. Formaldehyde is both a source of peroxy radicals (through photolysis and $\mathrm{OH}$ oxidation) and is produced from the peroxy radical reactions with NO. Figure 6b correlates peroxy radical and formaldehyde concentrations to the $\mathrm{HO}_{2}$ production rate from formaldehyde photolysis. In the radical channel (14), one $\mathrm{HCHO}$ molecule yields two $\mathrm{HO}_{2}$ molecules upon photolysis

$$
\begin{aligned}
\mathrm{HCHO}+h v & \rightarrow \mathrm{H}_{2}+\mathrm{CO} \\
& \rightarrow \mathrm{H}+\mathrm{HCO} \\
\mathrm{H}+\mathrm{O}_{2}+\mathrm{M} & \rightarrow \mathrm{HO}_{2}+\mathrm{M} \\
\mathrm{HCO}+\mathrm{O}_{2} & \rightarrow \mathrm{HO}_{2}+\mathrm{CO} \\
\text { Overall }: \mathrm{HCHO}+2 \mathrm{O}_{2}+h v & \rightarrow 2 \mathrm{HO}_{2}+\mathrm{CO}
\end{aligned}
$$

The good correlation is suggestive of persistent peroxy radical levels in the late afternoon having a major contribution from formaldehyde photolysis.

An interesting phenomenon was observed on a number of days (namely 9, 15, 17 and 21 August and 1 September);

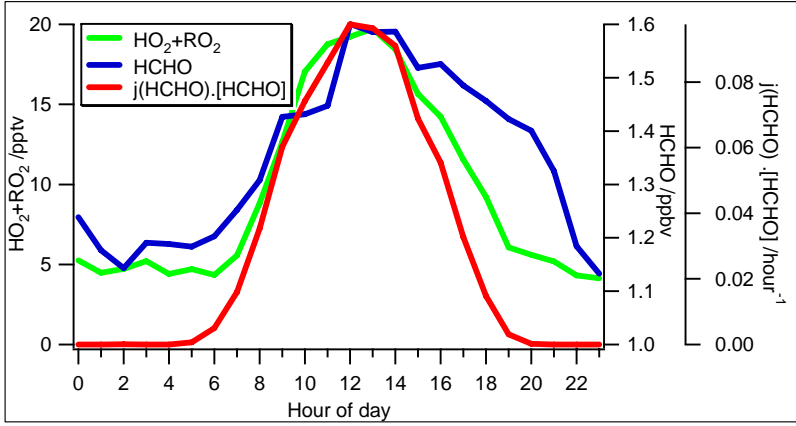

(a)

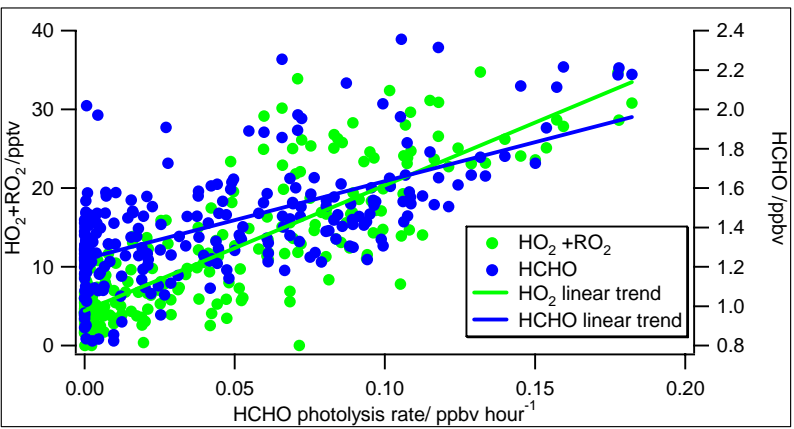

(b)

Fig. 6. (a) Hourly-averaged diurnal cycle of [HCHO], $\left[\mathrm{HO}_{2}+\sum \mathrm{RO}_{2}\right]$ and $j(\mathrm{HCHO}) \times[\mathrm{HCHO}]$, (b) Trend of ten minuteaveraged $\left[\mathrm{HO}_{2}+\sum \mathrm{RO}_{2}\right]$ and $[\mathrm{HCHO}]$ vs. $j(\mathrm{HCHO}) \times[\mathrm{HCHO}]$ $\left(\mathrm{r}_{(\mathrm{HCHO})}^{2}=0.626, \mathrm{r}^{2}\left(\mathrm{HO}_{2}+\sum \mathrm{RO}_{2}\right)=0.834\right)$.

when the solar intensity and photolysis rates showed a sudden increase in the early evening and a disproportionately large peroxy radical increase was observed. On 21 August (see case day 21st August in Fig. 7c) a peak in the $j\left(\mathrm{O}^{1} \mathrm{D}\right)$ was accompanied by a sudden peroxy radical increase at around 17:00. The same increase in $[\mathrm{OH}]$ was observed by (Smith et al., 2006) on this day, and was reflected in the modelled [OH] (Sommariva et al., 2006a). The $\mathrm{HO}_{2}$ measurements did not show a similar increase. One possible explanation for the phenomena is that if there are clouds at a given height as the sun nears the horizon light passes beneath the cloud at high zenith angles, rather than been attenuated by them, giving a short-lived boost to photochemical peroxy radical production (see for example, Monks et al., 2004).

\subsection{Peroxy radicals and $\mathrm{NO}_{\mathrm{x}}$}

$\mathrm{NO}_{\mathrm{x}}$ concentrations of greater than $0.5 \mathrm{ppbv}$ and up to as high as $300 \mathrm{pptv}$ on 8th, 16th and 21st August (see Fig. 2). The trajectories on the 8,16 and 21 August were classified as W, despite some local polluted SE winds. $\left[\mathrm{NO}_{\mathrm{x}}\right] /\left[\mathrm{NO}_{\mathrm{y}}\right]$ were higher than average on 13,14 and 16 August (days where local pollution re-circulated at the site). All the case days (8 August, 16 August and 21 August) in Fig. 7a, b and c had very high $\left[\mathrm{NO}_{\mathrm{x}}\right]$ and a peroxy radical diurnal profile that is shifted towards the evening. This may be due to a 


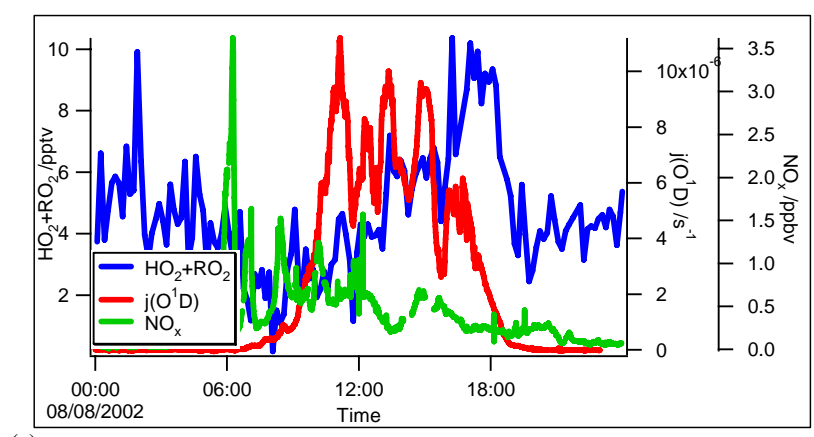

(a)

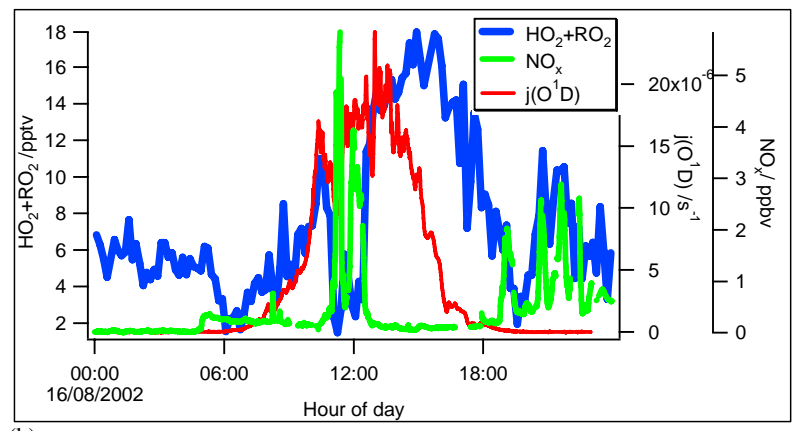

(b)

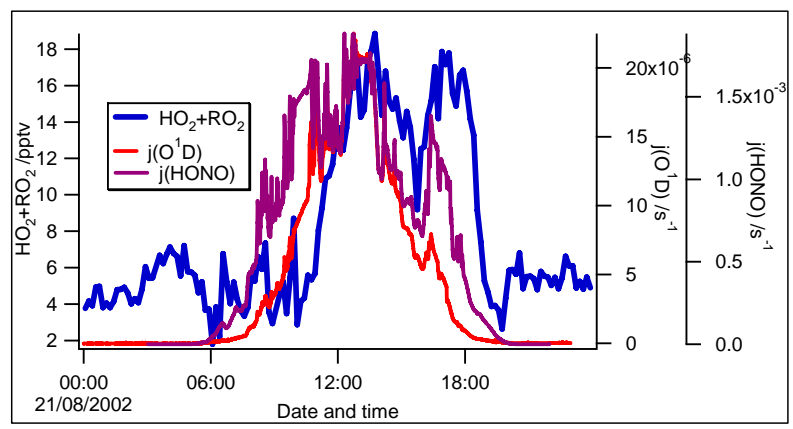

(c)

Fig. 7. Case study days: (a) 8 August, (b) 16 August, (c) 21 August $\left[\mathrm{HO}_{2}+\sum \mathrm{RO}_{2}\right], j\left(\mathrm{O}^{1} \mathrm{D}\right)\left(\right.$ and $\left[\mathrm{NO}_{\mathrm{x}}\right]$ or $\left.j(\mathrm{HONO})\right)$ diurnal cycles.

suppression of peroxy radical formation when $\mathrm{NO}_{\mathrm{x}}$ was high, and a sudden period of formation later in the day when $\mathrm{NO}_{\mathrm{x}}$ levels dropped.

The campaign average $\left[\mathrm{NO}_{\mathrm{x}}\right]$ diurnal cycle is shown in Fig. 3. The values are highest between 09:00 and 12:00. High $\mathrm{NO}_{\mathrm{x}}$ levels in the morning can suppress the radical levels via the repartitioning of $\mathrm{HO}_{2}$ to $\mathrm{OH}$. $\mathrm{NO}_{\mathrm{x}}$ suppression may, indeed, contribute to the apparent shift in the maxima of the peroxy radical diurnal cycle. On 16 August in Fig. 7b a sudden $\mathrm{NO}_{\mathrm{x}}$ spike in the morning perturbed the peroxy radical concentrations, moving the apparent maximum towards the afternoon.

Mean peroxy radical concentrations vs. binned $\left[\mathrm{NO}_{\mathrm{x}}\right]$ (on a logarithmic scale) for all 10-min data are shown in Fig. 8a. The $\mathrm{NO}_{\mathrm{x}}$ binning was taken at (equal) log normal intervals. The peroxy radical data were divided into two regimes according to $j\left(\mathrm{O}^{1} \mathrm{D}\right)$ values; $j\left(\mathrm{O}^{1} \mathrm{D}\right)>7.5 \times 10^{-6} \mathrm{~s}^{-1}$ represents daylight values and $<3 \times 10^{-7} \mathrm{~s}^{-1}$ that represents night-time conditions, which are discussed later (Fleming et al., 2006).

The data with $j\left(\mathrm{O}^{1} \mathrm{D}\right)>7.5 \times 10^{-6} \mathrm{~s}^{-1}$ (daylight hours) are used for investigating the effect of $\mathrm{NO}_{\mathrm{x}}$ on peroxy radicals during the day. Peroxy radical concentrations decrease with increasing $\left[\mathrm{NO}_{\mathrm{x}}\right]$ until values of about $0.1 \mathrm{ppbv}\left[\mathrm{NO}_{\mathrm{x}}\right]$. This shift is a result of changes in the $\mathrm{HO}_{2}: \mathrm{OH}$ ratios towards $\mathrm{OH}$ (reactions of $\mathrm{HO}_{2}$ and $\mathrm{RO}_{2}$ with $\mathrm{NO}$ to form $\mathrm{NO}_{2}$ ). Between values of 0.1 and $0.2 \mathrm{ppbv}\left[\mathrm{NO}_{\mathrm{x}}\right]$, there is a sudden increase in $\left[\mathrm{HO}_{2}+\sum \mathrm{RO}_{2}\right]$, which suggests a switch between $\mathrm{NO}_{\mathrm{x}}$ and VOC-limited conditions with respect to ozone production. The corresponding increase in VOCs at $\left[\mathrm{NO}_{\mathrm{x}}\right]$ above $0.1 \mathrm{ppbv}$ would lead to a rise in $\mathrm{OH}$ oxidation of VOCs, producing more peroxy radicals. Above $0.2 \mathrm{ppbv}\left[\mathrm{NO}_{\mathrm{x}}\right]$, increasing $\left[\mathrm{NO}_{\mathrm{x}}\right]$ appears to lower $\left[\mathrm{HO}_{2}+\sum \mathrm{RO}_{2}\right]$.

Hourly averaged daylight (06:00-19:00) alkane, isoprene, $\mathrm{HCHO}, \mathrm{CO}$ and $\mathrm{CH}_{4}$ concentrations, as well as peroxy radical levels, are plotted against binned $\mathrm{NO}_{\mathrm{x}}$ in Fig. $8 \mathrm{~b}$. The right hand axis is scaled for each hydrocarbon. The sharp increase in all VOCs at $\left[\mathrm{NO}_{\mathrm{x}}\right]>0.1 \mathrm{ppbv}$ would have a strong link to the rise in peroxy radicals at this time. These high VOC levels change the reactive mixture with respect to peroxy radical speciation. Sudden $\mathrm{NO}_{\mathrm{x}}$ increases could reflect changing air-mass composition. Concentrations of the biogenic hydrocarbon, isoprene peak at a lower $\left[\mathrm{NO}_{\mathrm{x}}\right]$ than the corresponding anthropogenic hydrocarbons. At higher $\left[\mathrm{NO}_{\mathrm{x}}\right]$, it is not clear which hydrocarbons govern the organic peroxy radical concentrations. Until $0.1 \mathrm{ppbv}\left[\mathrm{NO}_{\mathrm{x}}\right]$, the peroxy radical trend with increasing $\left[\mathrm{NO}_{\mathrm{x}}\right]$ is very similar to the $\mathrm{HCHO}$ trend. At $\left[\mathrm{NO}_{\mathrm{x}}\right]$ between 0.5 and 1 ppbv the dependence of peroxy radicals on VOCs is very clear, as a drop in all VOCs is reflected in the peroxy radical data.

The rural marine boundary location of Mace Head was seen to be representative of background chemistry but polluted air masses regularly reach the site, bringing higher $\mathrm{NO}_{\mathrm{x}}$ levels than experienced in the marine $\mathrm{W}$ air-masses as shown in Rickard et al. (2002). The switch to a significant VOC contribution to $\left[\mathrm{HO}_{2}+\sum \mathrm{RO}_{2}\right]$ occurs at a lower $\left[\mathrm{NO}_{\mathrm{x}}\right]$ level than at more polluted continental urban locations, such as at the BERLIOZ campaign where the maximum $\left[\mathrm{HO}_{2}\right]$ was at 1 ppbv $\left[\mathrm{NO}_{\mathrm{x}}\right]$ (Holland et al., 2003).

\subsection{Hydrocarbons and $\mathrm{HO}_{2} /\left(\mathrm{HO}_{2}+\sum \mathrm{RO}_{2}\right)$ ratios}

The highest mixing ratio of anthropogenic source compounds such as ethene, toluene and benzene was observed between 1 and 5 August. This illustrates the more polluted VOC-laden air masses, originating from the NE sector, passing over Scandinavia, northern Britain and Ireland.

High isoprene concentrations between the 2nd and 4th August were followed immediately by a sharp increase in DMS and this was also seen on 17 and 30 August. DMS concentrations varied from concentrations barely above the detection 


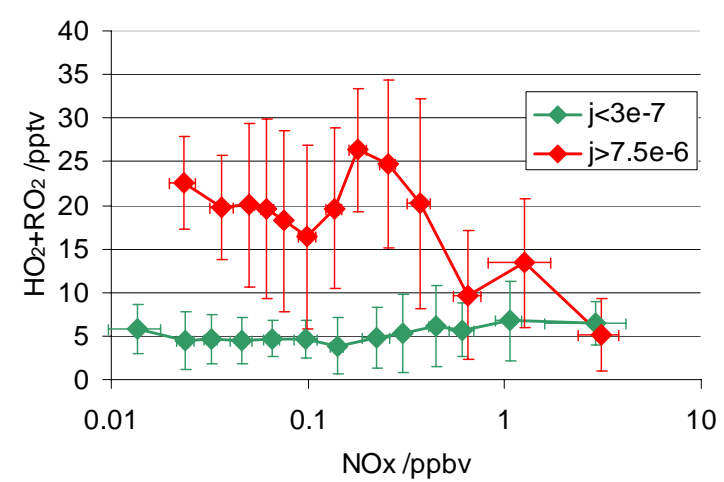

(a)

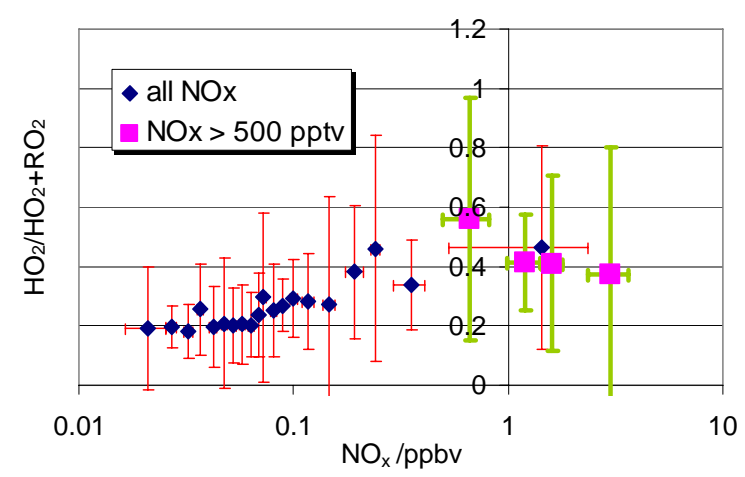

(c)

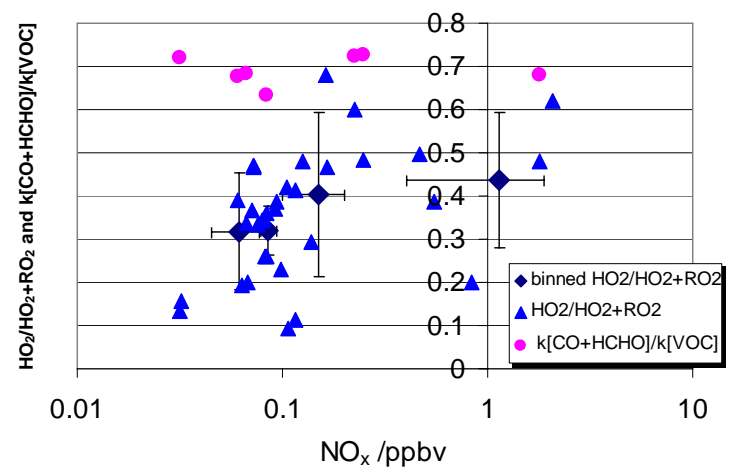

(e)

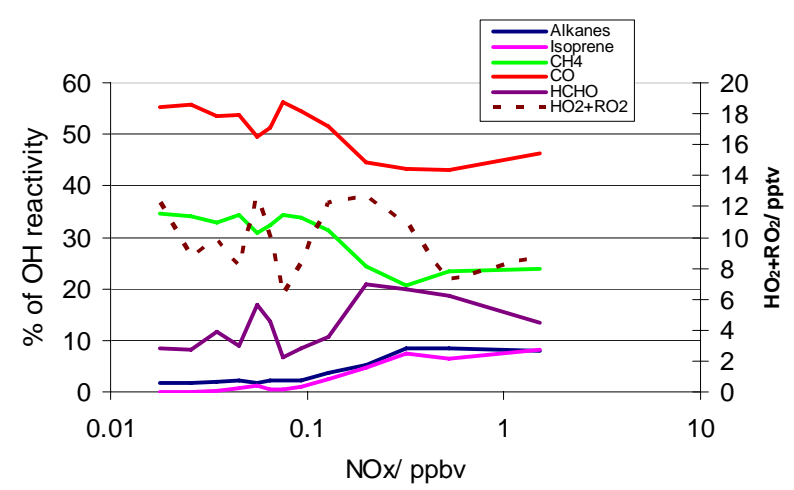

(b)

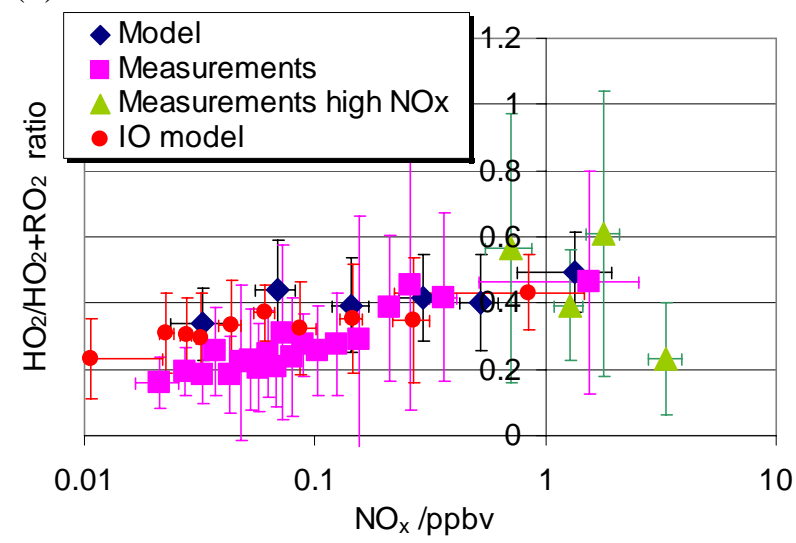

(d)

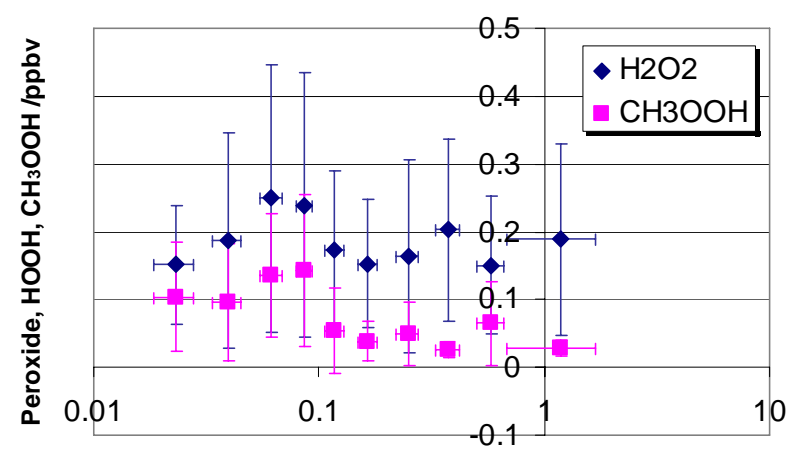

$\mathrm{NO}_{x} / \mathrm{ppbv}$

(f)

Fig. 8. (a) 10 minute-averaged $\left[\mathrm{HO}_{2}+\sum \mathrm{RO}_{2}\right]$ vs. $\left[\mathrm{NO}_{\mathrm{x}}\right]$ at two light intensity regimes; (b) Hourly-averaged daylight (06:00-19:00 UT) percentage contribution to $\mathrm{OH}$ reactivities for VOCs, $\mathrm{CO}$ and $\left[\mathrm{HO}_{2}+\sum \mathrm{RO}_{2}\right]$ vs. $\left[\mathrm{NO}_{\mathrm{x}}\right] ;(\mathbf{c}) \mathrm{HO}_{2} /\left(\mathrm{HO}_{2}+\sum \mathrm{RO}_{2}\right)$ vs. $\left[\mathrm{NO}_{\mathrm{x}}\right]$ : 15 minuteaveraged data with values at $\left[\mathrm{NO}_{\mathrm{x}}\right]>500 \mathrm{pptv}$ in smaller bins; (d) Measured and modelled $\mathrm{HO}_{2} /\left(\mathrm{HO}_{2}+\sum \mathrm{RO}_{2}\right)$ ratios vs. [NO $]$ for hourlyaverages (Model days: 1, 2, 9, 10, 15-22, 31 August and 1 September - model runs both full-oxy with and without halogens (see Table 4)); (e) Hourly-averaged $\mathrm{HO}_{2} /\left(\mathrm{HO}_{2}+\sum \mathrm{RO}_{2}\right)$ and $\phi(\mathrm{CO}+\mathrm{HCHO})$ vs. $\left[\mathrm{NO}_{\mathrm{x}}\right]$; (f) Hourly-averaged [peroxide] vs. [NO ]; for details of binning procedure, see text.

limit to as high as $900 \mathrm{pptv}$, with a spike of over $1.5 \mathrm{ppbv}$ on 28 July. DMS levels were highest in the W, N and SW sectors, as shown in Table 1.
$\mathrm{OH}$ reacts with hydrocarbons, forming organic radicals, which rapidly react with $\mathrm{O}_{2}$ to form peroxy radicals (see Reactions 10 and 11). Lewis et al. (2005) calculated the percentage contribution to $\mathrm{OH}$ removal by VOCs by com- 


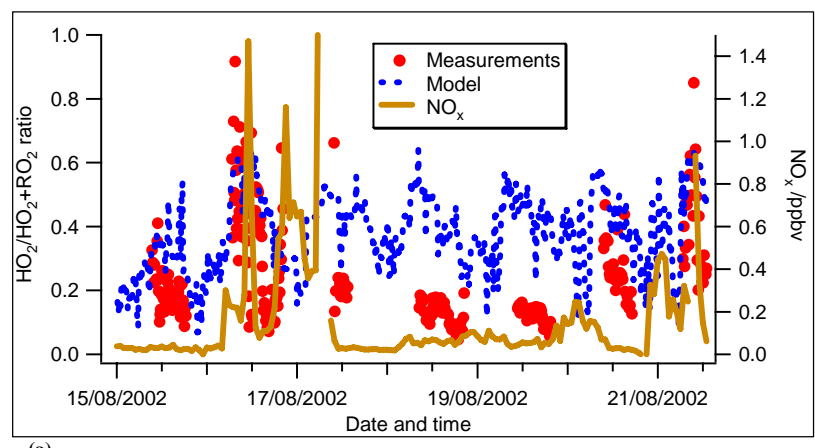

(a)

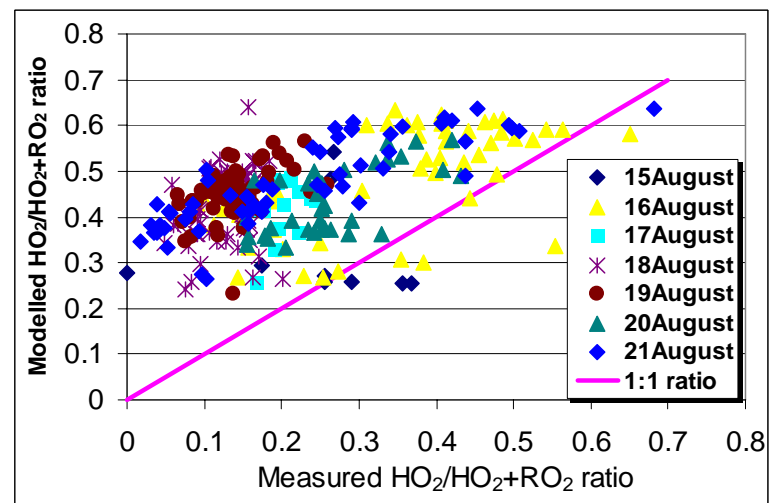

(b)

Fig. 9. (a) Hourly-averaged measured and modelled $\left[\mathrm{HO}_{2}+\sum \mathrm{RO}_{2}\right]$ diurnal cycles for the 15th-21st August (b) Measured and modelled $\mathrm{HO}_{2} / \mathrm{HO}_{2}+\mathrm{RO}_{2}$ ratios 15-21 August.

bining all the VOC-OH reaction rates, $k_{\mathrm{VOC}}[\mathrm{VOC}][\mathrm{OH}]$. Acetaldehyde accounted for up to $20 \%, \mathrm{CH}_{4}$, and formaldehyde both up to $30 \%$ and the other measured non-methane hydrocarbons (NMHCs) between 10 and $15 \%$ of $\mathrm{OH}$ loss. $\mathrm{HO}_{2}$ measurements taken by FAGE (Smith et al., 2006) provide a means of comparing $\mathrm{HO}_{2}$ with $\mathrm{HO}_{2}+\sum \mathrm{RO}_{2}$. Figure 9 shows the measured and modelled (full + oxy, heterogeneous with IO chemistry, see Table 4), hourly-averaged $\mathrm{HO}_{2} / \mathrm{HO}_{2}+\sum \mathrm{RO}_{2}$ ratios during the period 15-22 August. The addition of halogens to the system can repartition both $\mathrm{OH}$ and $\mathrm{HO}_{2}$ and $\mathrm{NO}$ and $\mathrm{NO}_{2}$ (e.g. Monks, 2005) via

$\mathrm{XO}+\mathrm{HO}_{2} \rightarrow \mathrm{HOX}+\mathrm{O}_{2}$

$\mathrm{HOX}+h v \rightarrow \mathrm{X}+\mathrm{OH}$

and

$\mathrm{XO}+\mathrm{NO} \rightarrow \mathrm{X}+\mathrm{NO}_{2}$

The measured $\mathrm{HO}_{2} /\left(\mathrm{HO}_{2}+\sum \mathrm{RO}_{2}\right)$ ratios are lower when $\left[\mathrm{NO}_{\mathrm{x}}\right]$ is low as on 18 and 19 August and can reach values over 1 when $\mathrm{NO}_{\mathrm{x}}$-laden air arrives at the site. The $\mathrm{HO}_{2} /\left(\mathrm{HO}_{2}+\sum \mathrm{RO}_{2}\right)$ ratio generally decreases from the start of the day towards sunset. The equivalent model ratio shows a similar diurnal profile from day to day, with the distinct diurnal profile displaying the highest $\mathrm{HO}_{2} / \mathrm{HO}_{2}+\sum \mathrm{RO}_{2}$ ratios at midday. Generally, the modelled $\mathrm{HO}_{2} / \mathrm{HO}_{2}+\sum \mathrm{RO}_{2}$ ratio is much higher than the measurement equivalent, except when $\mathrm{NO}_{\mathrm{x}}$ is high.

The correlation plot of modelled versus measured $\mathrm{HO}_{2} /\left(\mathrm{HO}_{2}+\sum \mathrm{RO}_{2}\right)$ ratios is shown in Fig. $9 \mathrm{~b}$, with the individual days marked in separate colours. The model generally over-predicts these ratios on all the days. The measured $\mathrm{HO}_{2} /\left(\mathrm{HO}_{2}+\sum \mathrm{RO}_{2}\right)$ ratio on 16 August (when local SE winds brought high $\mathrm{NO}_{\mathrm{x}}$ levels to the site) showed large variations throughout the day, both for the modelled and measured ratios as seen in both Figs. 9a and b. However, Fig. 9a shows that the measurement ratios displayed greater variability than the modelled ratio during the high $\mathrm{NO}_{\mathrm{x}}$ period on this day. The same is observed during the high $\mathrm{NO}_{\mathrm{x}}$ period on 21 August, where the model ratio appears not to be influenced by $\mathrm{NO}_{\mathrm{x}}$ variations.

To investigate the effect of varying $\mathrm{NO}_{\mathrm{x}}$ on the $\mathrm{HO}_{2} /\left(\mathrm{HO}_{2}+\sum \mathrm{RO}_{2}\right)$ ratio, a plot of $\mathrm{HO}_{2} /\left(\mathrm{HO}_{2}+\sum \mathrm{RO}_{2}\right)$ ratios against binned $\left[\mathrm{NO}_{\mathrm{x}}\right]$ is shown in Fig. 8c. The ratio of inorganic to organic peroxy radicals increases as $\left[\mathrm{NO}_{\mathrm{x}}\right]$ increases. The highest $\left[\mathrm{NO}_{\mathrm{x}}\right]$ bin at $1 \mathrm{ppbv}$ has been divided into smaller bins in order to study the structure at high $\mathrm{NO}_{\mathrm{x}}$. At $\left[\mathrm{NO}_{\mathrm{x}}\right]>0.8 \mathrm{ppbv}$, the $\mathrm{HO}_{2} /\left(\mathrm{HO}_{2}+\sum \mathrm{RO}_{2}\right)$ ratio appears to decrease with increasing $\left[\mathrm{NO}_{\mathrm{x}}\right]$.

Figure $8 \mathrm{~d}$ shows the measured and modelled $\mathrm{HO}_{2} /\left(\mathrm{HO}_{2}+\right.$ $\sum \mathrm{RO}_{2}$ ) ratios plotted against $\left[\mathrm{NO}_{\mathrm{X}}\right]$. Two model runs (with and without IO) are plotted to show the effect of halogens. In general, the $\mathrm{HO}_{2} /\left(\mathrm{HO}_{2}+\sum \mathrm{RO}_{2}\right)$ ratio is higher in the model but the model does not show a strong increase with increasing $\left[\mathrm{NO}_{\mathrm{x}}\right] . \mathrm{HO}_{2} /\left(\mathrm{HO}_{2}+\sum \mathrm{RO}_{2}\right)$ ratios at high $\left[\mathrm{NO}_{\mathrm{x}}\right]$ for both model and measured values are very similar, but at lower $\left[\mathrm{NO}_{\mathrm{x}}\right]$ the model predicts higher $\mathrm{HO}_{2} /\left(\mathrm{HO}_{2}+\sum \mathrm{RO}_{2}\right)$ ratios. Interestingly, the addition of halogen chemistry improves the agreement between model and measurement, indicating a role for the $\mathrm{IO}$ in repartitioning the $\mathrm{OH}$ and $\mathrm{HO}_{2}$ via Reactions (17) and (18). It is clear that at low $\left[\mathrm{NO}_{\mathrm{x}}\right]$ the halogens seem to be more important. Sommariva et al. (2006) found that the model mechanism worked better at high $\mathrm{NO}_{\mathrm{x}}$, indicating that peroxy - peroxy reactions at low $\mathrm{NO}_{\mathrm{x}}$ are still not fully understood. An earlier Mace Head campaign tailored box model, without OVOC and halogen chemistry, used on Mace Head data, over-predicted $\mathrm{HO}_{2} /\left(\mathrm{HO}_{2}+\mathrm{RO}_{2}\right)$ at low $\mathrm{NO}_{\mathrm{x}}$ and under-predicted at high $\mathrm{NO}_{\mathrm{x}}$ (Carslaw et al., 1999, 2002). As previously stated, oxidation of $\mathrm{CO}, \mathrm{CH}_{4}$, $\mathrm{HCHO}$ and NMHCs represents a large loss term for $\mathrm{OH}$. The reaction of $\mathrm{OH}$ with $\mathrm{CO}$ and $\mathrm{HCHO}$ leads to the formation of $\mathrm{HO}_{2}$. $\mathrm{OH}$ reaction with $\mathrm{CH}_{4}$ forms $\mathrm{CH}_{3} \mathrm{O}_{2}$ and $\mathrm{OH}$ reaction with VOC forms predominantly $\mathrm{RO}_{2}$. The fraction of $\mathrm{OH}$ removal reactions that form $\mathrm{HO}_{2}$ can be represented as:

$$
\left(\frac{k_{\mathrm{CO}}[\mathrm{CO}]+k_{\mathrm{HCHO}}[\mathrm{HCHO}]}{k_{\mathrm{CO}}[\mathrm{CO}]+k_{\mathrm{HCHO}}[\mathrm{HCHO}]+k_{\mathrm{CH}_{4}}+k_{\mathrm{VOC}}[\mathrm{VOC}]}\right)
$$




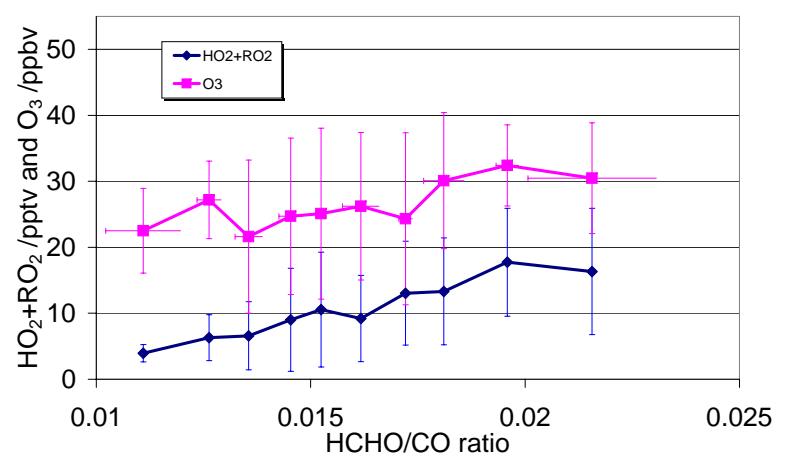

Fig. 10. Hourly-averaged $\left[\mathrm{HO}_{2}+\mathrm{RO}_{2}\right]$ and $\left[\mathrm{O}_{3}\right]$ vs. [HCHO]/[CO].

where $k_{\mathrm{CO}}, k_{\mathrm{HCHO}}, k_{\mathrm{CH}_{4}}$ and $k_{\mathrm{VOC}}$ are the rate coefficients for the reaction of $\mathrm{OH}$ with $\mathrm{CO}, \mathrm{HCHO}, \mathrm{CH}_{4}$ and VOCs respectively. The rate-coefficients were taken from the $\mathrm{Na}$ tional Institute of Standards and Technology (NIST) web site.

The $\phi(\mathrm{CO}+\mathrm{HCHO})$ fraction was calculated for the days that had complete $\mathrm{CO}, \mathrm{CH}_{4}$ and VOC and $\mathrm{HCHO}$ concentrations, as in Lewis et al. (2005). Comparing $\phi(\mathrm{CO}+\mathrm{HCHO})$ ratios with $\mathrm{HO}_{2} /\left(\mathrm{HO}_{2}+\sum \mathrm{RO}_{2}\right)$ ratios should be indicative of whether $\mathrm{HO}_{2} /\left(\mathrm{HO}_{2}+\sum \mathrm{RO}_{2}\right)$ ratio variations were caused primarily by varying $\mathrm{HCHO}, \mathrm{CO}, \mathrm{CH}_{4}$ and VOC concentrations.

Figure 8e shows a plot of hourly $\mathrm{HO}_{2} /\left(\mathrm{HO}_{2}+\sum \mathrm{RO}_{2}\right)$ and $\phi(\mathrm{CO}+\mathrm{HCHO})$ ratios against binned $\left[\mathrm{NO}_{\mathrm{x}}\right]$. The trend for increasing $\mathrm{HO}_{2} /\left(\mathrm{HO}_{2}+\sum \mathrm{RO}_{2}\right)$ with increasing $\left[\mathrm{NO}_{\mathrm{x}}\right]$ is not replicated for $\phi(\mathrm{CO}+\mathrm{HCHO})$, which does not appear effected by $\mathrm{NO}_{\mathrm{x}}$. $\mathrm{HO}_{2} /\left(\mathrm{HO}_{2}+\sum \mathrm{RO}_{2}\right)$ ratios are always lower than $\phi(\mathrm{CO}+\mathrm{HCHO})$ ratios $(<0.5$ for $\mathrm{HO}_{2} /\left(\mathrm{HO}_{2}+\mathrm{RO}_{2}\right)$ and $>0.5$ for $\left.\phi(\mathrm{CO}+\mathrm{HCHO})\right)$. The ratio of $k[\mathrm{HCHO}] /(k[\mathrm{HCHO}]+k[\mathrm{CO}])$ was found to remain constant at around 0.5 , showing that $\mathrm{HCHO}$ and $\mathrm{CO}$ contribute equally to $\mathrm{HO}_{2}$ formation. $\phi(\mathrm{CO}+\mathrm{HCHO})$ ratios have a range of between 0.3 and 2.5 in NAMBLEX, much greater than the $\mathrm{HO}_{2} /\left(\mathrm{HO}_{2}+\sum \mathrm{RO}_{2}\right)$ ratio range. The $\phi(\mathrm{CO}+\mathrm{HCHO})$ ratios were usually much higher than $\mathrm{HO}_{2} /\left(\mathrm{HO}_{2}+\sum \mathrm{RO}_{2}\right)$ ratios, which suggests that modelling the VOC-OH reactivity underestimates the resulting $\mathrm{RO}_{2}$ concentrations with respect to $\mathrm{HO}_{2}$. Also, calculating $\mathrm{HO}_{2}$ to be directly correlated with $\mathrm{CO}$ and $\mathrm{HCHO}$ reactivity is not necessarily valid as $\mathrm{HCHO}$ is both photolysed and is oxidised by $\mathrm{OH}$ to form $\mathrm{HO}_{2}$. $\mathrm{HCHO}$ is also formed from the reaction of $\mathrm{CH}_{3} \mathrm{O}_{2}$ with $\mathrm{NO}$ (Reactions 2 and 3).

The HCHO:CO ratio can be used as a tracer to distinguish different air masses and differing times since the last major input from pollution. It is of interest because both tracers are primary pollutants, but formaldehyde is also produced in the troposphere by oxidation of $\mathrm{CH}_{4}$ in the presence of $\mathrm{NO}_{\mathrm{x}}$. Subsequent photolysis of this formaldehyde then produces $\mathrm{CO}$. In polluted high $\mathrm{NO}_{\mathrm{x}}$ environments, HCHO production is more important than its pho- (a)

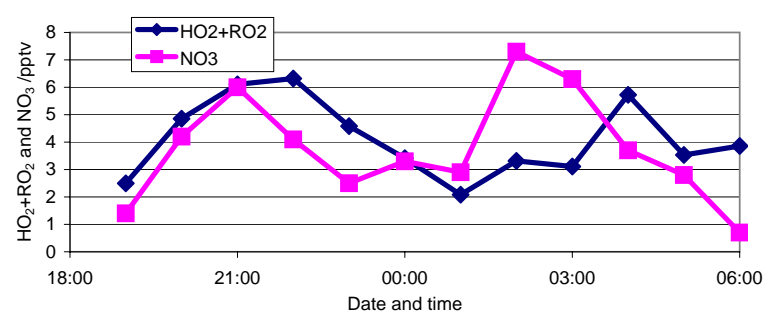

(b)

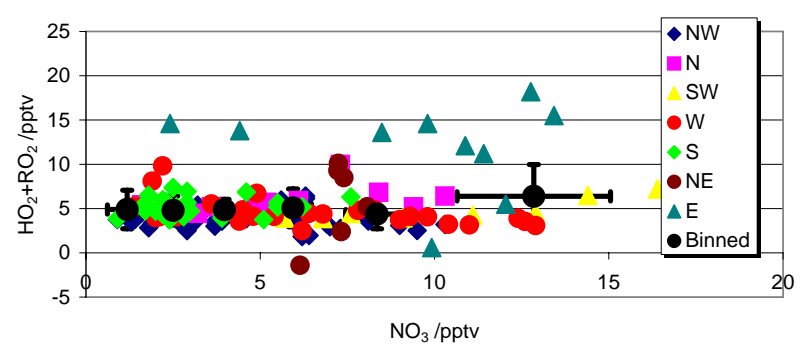

(c)

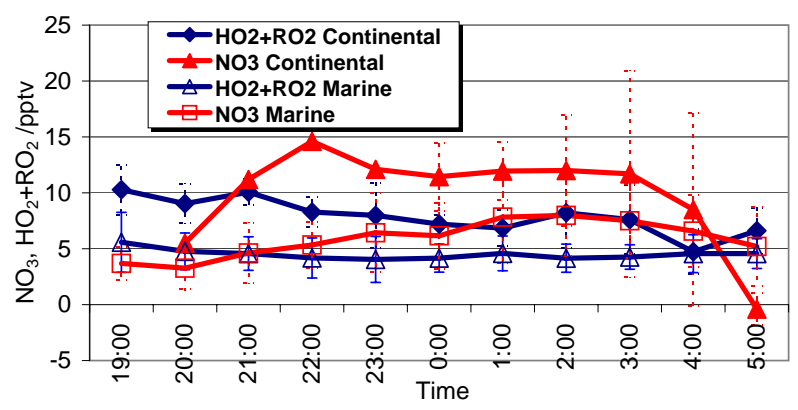

Fig. 11. (a) Typical nightime profile of $\left[\mathrm{HO}_{2}+\sum \mathrm{RO}_{2}\right]$ and $\left[\mathrm{NO}_{3}\right]$ for the night of 28/29 August; (b) Hourly-averaged $\left[\mathrm{HO}_{2}+\sum \mathrm{RO}_{2}\right]$ vs. $\left[\mathrm{NO}_{3}\right]$ for air-mass sectors. Large black markers represent all campaign data divided into six bins according to $\mathrm{NO}_{3}$ with the corresponding $(1 \sigma)$ standard deviations; $(\mathbf{c})\left[\mathrm{NO}_{3}\right]$ and $\left[\mathrm{HO}_{2}+\sum \mathrm{RO}_{2}\right]$ at night (19:00 to 06:00) with the $(1 \sigma)$ standard deviation within each hour.

tolysis and the $\mathrm{HCHO}: \mathrm{CO}$ ratio increases. Figure 10 shows that both $\left[\mathrm{HO}_{2}+\sum \mathrm{RO}_{2}\right]$ and $\left[\mathrm{O}_{3}\right]$ increase with increasing $\mathrm{HCHO} / \mathrm{CO}$. If higher $\mathrm{HCHO}: \mathrm{CO}$ ratios are a marker for polluted conditions, then this would be likely to lead to higher ozone levels. Higher peroxy radical levels at increased $\mathrm{HCHO}$ suggests that $\mathrm{HCHO}$ is more effective at producing peroxy radicals than $\mathrm{CO}$. The $\phi(\mathrm{CO}+\mathrm{HCHO})$ ratio presumes that $\mathrm{HCHO}$ and $\mathrm{CO}$ have equal $\mathrm{HO}_{2}$ productivity, so any discrepancy between $\phi(\mathrm{CO}+\mathrm{HCHO})$ and $\mathrm{HO}_{2} / \mathrm{HO}_{2}+\sum \mathrm{RO}_{2}$ may be due to the inaccuracy of predicting $\mathrm{HO}_{2}$ from $\phi(\mathrm{CO}+\mathrm{HCHO})$.

\subsection{Peroxides}

The highest $\mathrm{H}_{2} \mathrm{O}_{2}$ concentrations of up to 0.5 pptv were between 1 and 3 August when $\mathrm{NO}_{\mathrm{x}}$ and hydrocarbon concen- 
trations were high. Indeed, in Table 1 , high $\mathrm{NO}_{\mathrm{x}}$ and high VOC concentrations in the $\mathrm{E}$ sector have lead to the highest peroxide concentrations. Morgan (2004) found a maximum $\left[\mathrm{H}_{2} \mathrm{O}_{2}\right]$ of $1.1 \mathrm{ppbv}$ with an average of $0.19 \mathrm{ppbv}$ during NAMBLEX, much lower than the maximum of 7.1 and mean of $1.58 \mathrm{ppbv}$ at Mace Head in June 1999 (Morgan and Jackson, 2002). In the clean marine boundary layer, such as Cape Grim, Tasmania, peroxy radicals are more likely to self-react to form peroxides than they are to react with $\mathrm{NO}$ and subsequently produce ozone (Ayers et al., 1997). Thus, high levels of peroxides would signify an ozone-destroying regime and a lower turnover rate of the various species that are part of the ozone-forming cycles.

Figure $8 \mathrm{f}$ shows [peroxide] versus $\left[\mathrm{NO}_{\mathrm{x}}\right]$ trends that are very similar in shape to peroxy radical $-\mathrm{NO}_{\mathrm{x}}$ trends in Fig. 8a, illustrating the strong link between peroxy radicals and $\mathrm{H}_{2} \mathrm{O}_{2}$ concentrations. $\mathrm{H}_{2} \mathrm{O}_{2}$ concentrations are highest at around $0.1 \mathrm{ppbv} \mathrm{NO}_{\mathrm{x}}$ and decrease slightly at higher $\mathrm{NO}_{\mathrm{x}}$ but do not decrease to the same extent as peroxy radical levels at high $\mathrm{NO}_{\mathrm{x}}$ as shown in in Fig. $8 \mathrm{a}$. $\mathrm{CH}_{3} \mathrm{O}_{2} \mathrm{H}$ is more influenced by $\mathrm{NO}_{\mathrm{x}}$ than $\mathrm{H}_{2} \mathrm{O}_{2}$, as it is reduced to nearly zero values at high $\mathrm{NO}_{\mathrm{x}}$.

\subsection{Night-time chemistry}

Table 3 shows night-time averages for the different air mass sectors and the concomitant $\mathrm{NO}_{3}$ measurements from data on fifteen nights (Saiz-Lopez et al., 2006; see also Bitter et al., 2005). The $\mathrm{E}$ and NE air-mass sectors have the highest average $\mathrm{O}_{3}, \mathrm{NO}_{3}$ (with the $\mathrm{E}$ sector having $\left[\mathrm{NO}_{3}\right]$ of 11.7 pptv, compared to less than $6 \mathrm{pptv}$ in all the other sectors) and total alkene concentrations as seen in Table 3. The highest nighttime peroxy radical concentrations are observed in the SE and E sectors (cf. Allan et al., 2000).

Sommariva et al. (2006b) found that the model had a tendency to underestimate night time peroxy radical levels except on 31 August and 1 September. Closer agreement between the model and measurements was achieved when moving from a "clean" model with only $\mathrm{CO}$ and $\mathrm{CH}_{4}$ to the full model with more complex hydrocarbons. Short-term $\mathrm{NO}_{\mathrm{x}}$ spikes during the night are often matched with elevated peroxy radical concentrations as high as $10 \mathrm{pptv}$, or even $25 \mathrm{pptv}$ in the polluted E period on 2 and 3 August. On 16 August, when $\left[\mathrm{NO}_{\mathrm{x}}\right]$ suddenly increased at about 20.00 , a significant rise in $\left[\mathrm{HO}_{2}+\sum \mathrm{RO}_{2}\right]$ followed closely, as shown in the case day in Fig. 7b. The same is not observed for the 8th d August (Fig. 7a). $\left[\mathrm{HO}_{2}+\sum \mathrm{RO}_{2}\right]$ vs. $\left[\mathrm{NO}_{\mathrm{x}}\right]$ for nights with $\mathrm{NO}_{3}$ data are shown in Fig. 8a. As $\left[\mathrm{NO}_{\mathrm{x}}\right]$ increases, $\left[\mathrm{HO}_{2}+\mathrm{RO}_{2}\right]$ increases at $\left[\mathrm{NO}_{\mathrm{x}}\right]>0.1 \mathrm{ppbv}$. This peroxy radical increase with $\mathrm{NO}_{\mathrm{x}}$ is suggestive of $\mathrm{NO}_{3}$ radicals (formed by $\mathrm{NO}_{2}+\mathrm{O}_{3}$ ) reacting with hydrocarbons to form peroxy radicals.

Figure 11a shows $\mathrm{NO}_{3}$ and $\mathrm{HO}_{2}+\sum \mathrm{RO}_{2}$ from a typical overnight period. Figure $11 \mathrm{~b}$ is a plot of average $\left[\mathrm{HO}_{2}+\right.$ $\left.\sum \mathrm{RO}_{2}\right]$ vs. $\left[\mathrm{NO}_{3}\right]$ (Saiz-Lopez et al., 2006) for all the airmass sectors. The $\left[\mathrm{HO}_{2}+\sum \mathrm{RO}_{2}\right]$ were separated into six

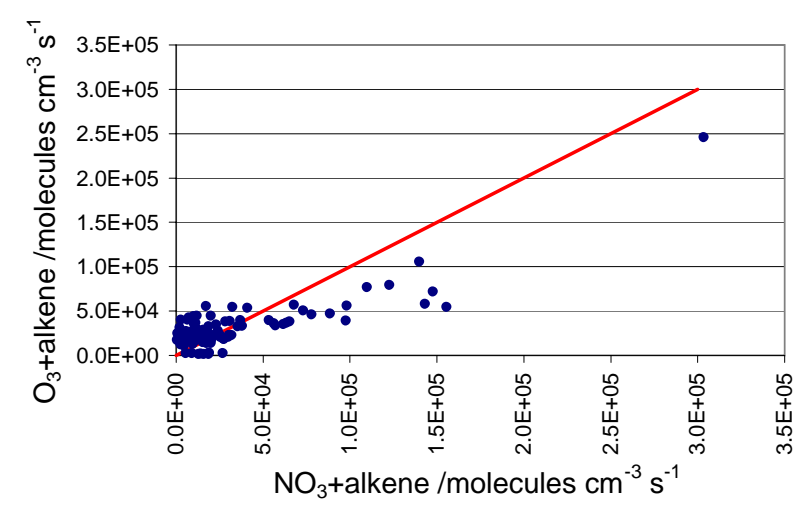

(a)

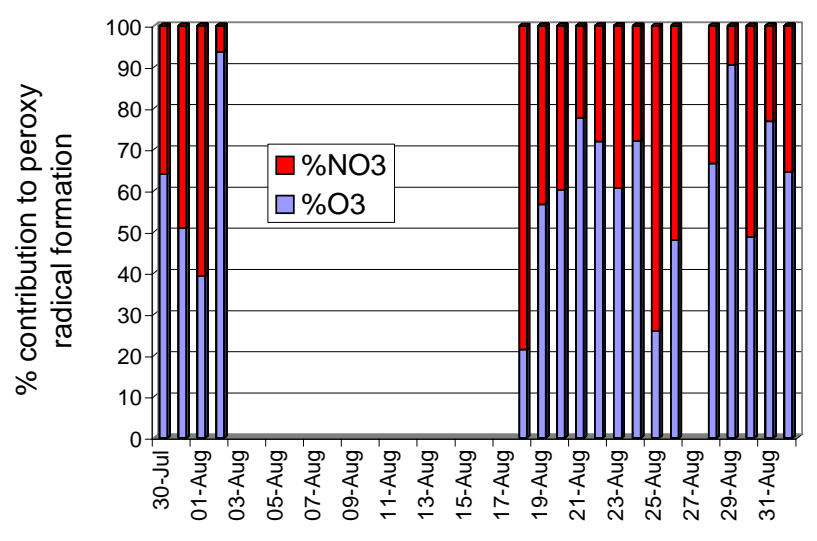

(b)

Fig. 12. (a) Flux of peroxy radicals formed from alkene- $\mathrm{NO}_{3}$ and alkene- $\mathrm{O}_{3}$ channels: Hourly-averaged night-time (19:00 to 06:00 UT)fluxes. The red-line is the 1:1 ratio; (b) Percentage contribution of $\mathrm{O}_{3}$ and $\mathrm{NO}_{3}$ to peroxy radical formation from alkene night-time reactions.

$\left[\mathrm{NO}_{3}\right]$ bins and plotted on the same graph with error bars showing their standard deviation. The E sector, even though $\left[\mathrm{NO}_{3}\right]$ varies widely, always has higher $\left[\mathrm{HO}_{2}+\sum \mathrm{RO}_{2}\right]$ than the other sectors, irrespective of $\left[\mathrm{NO}_{3}\right]$. Figure $11 \mathrm{c}$ shows the night-time profiles of $\left[\mathrm{NO}_{3}\right]$ and $\left[\mathrm{HO}_{2}+\sum \mathrm{RO}_{2}\right]$ for the entire marine (N, NW, SW and W combined) and continental (NE, E combined) air-mass sectors. The $\mathrm{NO}_{3}$ concentration was always higher in the continental sector. The peroxy radical concentration was also always higher in the continental sector. There does not appear to be a significant peroxy radical pattern throughout the night.

Rate constants for the reaction of $\mathrm{NO}_{3}$ with the measured alkenes were used to calculate the rate of the $\mathrm{NO}_{3}$ loss and the $\mathrm{O}_{3}$ reactions with alkenes (cf. Salisbury et al., 2001). The flux of peroxy radicals formed from the alkene reactions from the $\mathrm{NO}_{3}$ and $\mathrm{O}_{3}$ channels were compared by correlating all night-time hours of the campaign as shown in Fig. 12a. At low peroxy radical-forming fluxes, the ozone-alkene re- 


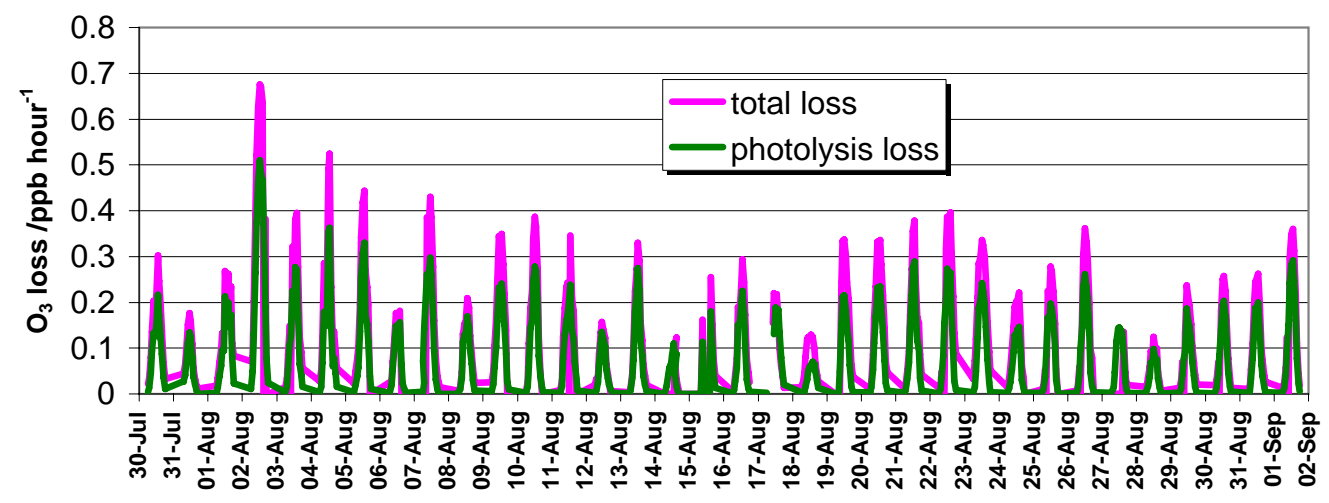

(a)

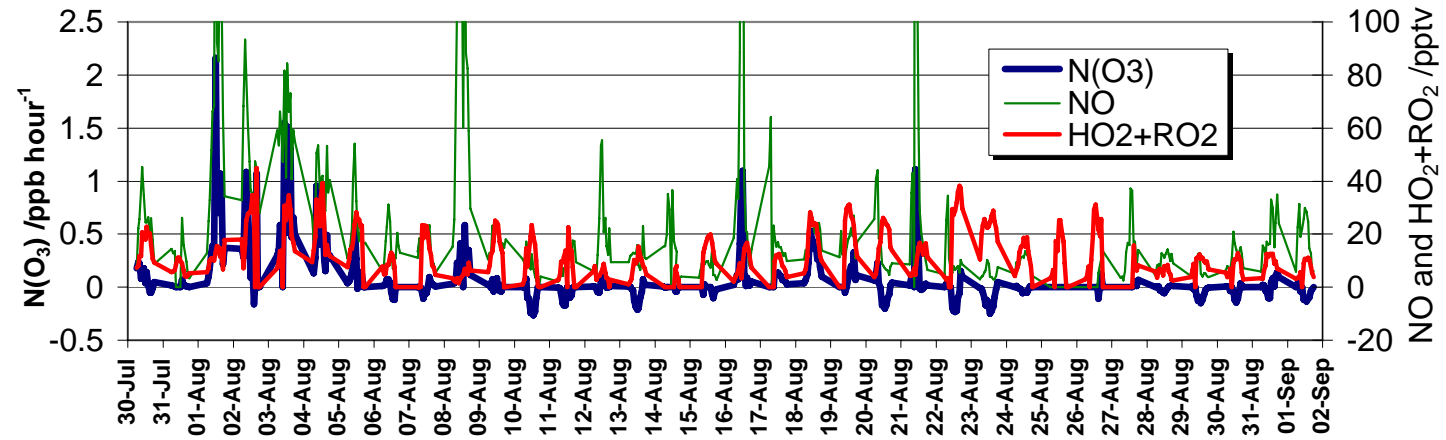

(b)

Fig. 13. (a) Total ozone loss and ozone loss via photolysis. (b) Net ozone production and corresponding $[\mathrm{NO}]$ and $\left[\mathrm{HO}_{2}+\sum \mathrm{RO}_{2}\right]$ used to calculate $\mathrm{P}\left(\mathrm{O}_{3}\right)$.

actions tended to dominate over the $\mathrm{NO}_{3}$-alkene reactions. When $\mathrm{NO}_{3}$ levels were high, the fluxes from $\mathrm{NO}_{3}$-alkene reactions were far higher than the ozone-alkene fluxes. At $\mathrm{NO}_{3}$-alkene fluxes above $5 \times 10^{4}$ molecules $\mathrm{cm}^{-3} \mathrm{~s}^{-1}$, the ozone-alkene flux was always lower than the $\mathrm{NO}_{3}$-alkene flux. Figure $12 \mathrm{~b}$ shows the percentage contribution to peroxy radical formation from alkene night-time reactions. This varies strongly from night to night, with high $\mathrm{NO}_{3}$ contributions on 18 and 25 August, receiving W and SW air-masses respectively. For the nights for which full data is available the overall contribution of ozone-alkene chemistry to peroxy radical production was $59 \%$ compared to $41 \%$ for $\mathrm{NO}_{3}$ alkene.

Peroxy radical levels were seen to decrease throughout the night in EASE 97 (Salisbury et al., 2001), with more polluted conditions experiencing less of a decrease throughout the night. Analysis to determine the percentage contribution of the ozone - alkene and $\mathrm{NO}_{3}$ reactions to form peroxy radicals was carried out for EASE 97 (Salisbury et al., 2001). The contribution of both was found to vary between 30 and $70 \%$, for each wind sector, but on the whole as with this study the ozone-alkene reaction was the dominant production mechanism. Carslaw et al. (1997) found a positive correlation between $\mathrm{HO}_{2}+\sum \mathrm{RO}_{2}$ and $\mathrm{NO}_{3}$ at the Weybourne Atmospheric Observatory (see also Geyer et al., 2003), while Mihelcic et al. (1993) found a negative correlation between per- oxy radicals and $\mathrm{NO}_{3}$ (presumably owing to highly variable reactive hydrocarbon fluxes) at Schauinsland. Any lack of correlation is not surprising, as $\mathrm{NO}_{3}$ is both a source (Wayne et al., 1991) and a sink (Biggs et al., 1994) of peroxy radicals.

\subsection{Photochemical production of ozone}

Net photochemical ozone formation, $\mathrm{N}\left(\mathrm{O}_{3}\right)$ (or ozone tendency) was calculated for each hour of the campaign between 06:00 and 19:00, using Eq. (3) (For assumptions inherent in this form of calculation see Salisbury et al., 2002). The production term represents $\mathrm{NO}_{2}$ formation and subsequent photolysis to form ozone (Reactions 1 to 4 ). $k_{p}$ is the combined rate coefficient for the oxidation of $\mathrm{NO}$ to $\mathrm{NO}_{2}$ by all peroxy radicals (Reactions 1 and 2). The loss term represents the reaction of ozone with $\mathrm{OH}$ and $\mathrm{HO}_{2}$ and ozone photolysis (where $f$ represents the fraction of $\mathrm{O}\left({ }^{1} \mathrm{D}\right.$ ) that reacts with $\mathrm{H}_{2} \mathrm{O}$ to form $\mathrm{OH}$ ).

$$
\begin{aligned}
& N\left(\mathrm{O}_{3}\right)=P\left(\mathrm{O}_{3}\right)-L\left(\mathrm{O}_{3}\right) \\
& N\left(\mathrm{O}_{3}\right)=k_{p}[\mathrm{NO}]\left[\mathrm{HO}_{2}+\Sigma \mathrm{RO}_{2}\right] \\
& -\left\{f . j\left(\mathrm{O}^{1} D\right)+k_{21}[\mathrm{OH}]+k_{6}\left[\mathrm{HO}_{2}\right]\right\}\left[\mathrm{O}_{3}\right]
\end{aligned}
$$

$\mathrm{HO}_{2}+\mathrm{O}_{3} \rightarrow \mathrm{OH}+2 \mathrm{O}_{2}$

$\mathrm{OH}+\mathrm{O}_{3} \rightarrow \mathrm{HO}_{2}+\mathrm{O}_{2}$ 


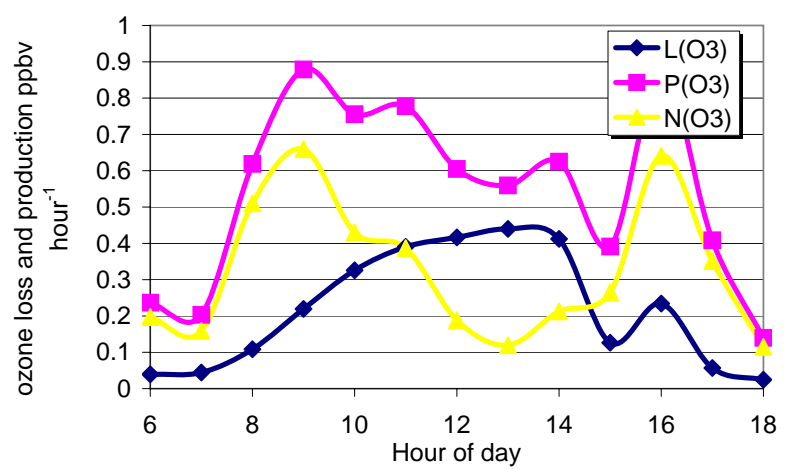

(a)

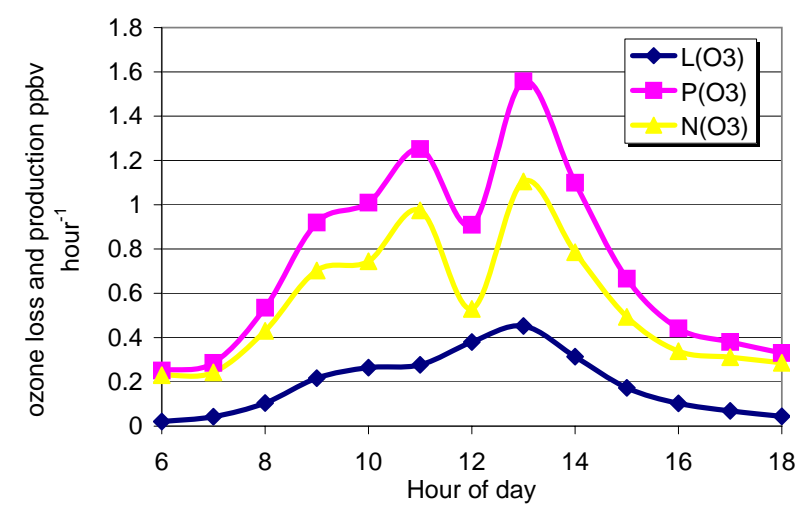

(b)

Fig. 14. Hourly-averaged loss, production and net ozone production for (a) Clean conditions (full days with SW/W wind direction) and(b) Polluted conditions (full days with NE/E wind direction).

Figure 13a shows a time series of calculated ozone loss for all campaign daylight hours. The largest contribution to the calculated loss is that of ozone photolysis. The average ozone loss chemistry was calculated to be $64 \%$ from ozone photolysis, $8 \%$ from the $\mathrm{OH}+\mathrm{O}_{3}$ reaction and $24 \%$ from the $\mathrm{HO}_{2}+\mathrm{O}_{3}$ reaction. The contributions from the three loss reactions vary from day to day, with total ozone loss varying between 0.1 and $0.7 \mathrm{ppbv} \mathrm{h}^{-1}$ at the solar maximum.

Figure $13 \mathrm{~b}$ is a plot of net ozone production, $\mathrm{N}\left(\mathrm{O}_{3}\right)$ throughout the campaign with $\left[\mathrm{HO}_{2}+\Sigma \mathrm{RO}_{2}\right]$ and [NO] plotted on the right-hand axis. The ozone production term, $\mathrm{P}\left(\mathrm{O}_{3}\right)$ is dependent on [NO] and $\left[\mathrm{HO}_{2}+\Sigma \mathrm{RO}_{2}\right]$, the ratio of which varies greatly from day to day, showing an inverse relationship during the daylight hours. [NO] was more variable than $\left[\mathrm{HO}_{2}+\Sigma \mathrm{RO}_{2}\right]$ during NAMBLEX. Lower [NO] leads to a smaller $\mathrm{P}\left(\mathrm{O}_{3}\right)$ term, which means that ozone loss becomes nearly as great as ozone production, leading to a few hours and days where $\mathrm{N}\left(\mathrm{O}_{3}\right)$ was negative.

Table 2 shows the average mixing ratios for a range of tracers and $\mathrm{N}\left(\mathrm{O}_{3}\right)$ for daylight (06:00-19:00 UT) hours with differing air mass sectors. Figure 14 shows the hourly-averaged ozone loss and production rates for NAMBLEX. The loss term follows $j\left(\mathrm{O}^{1} \mathrm{D}\right)$, peaking at solar noon, and does not

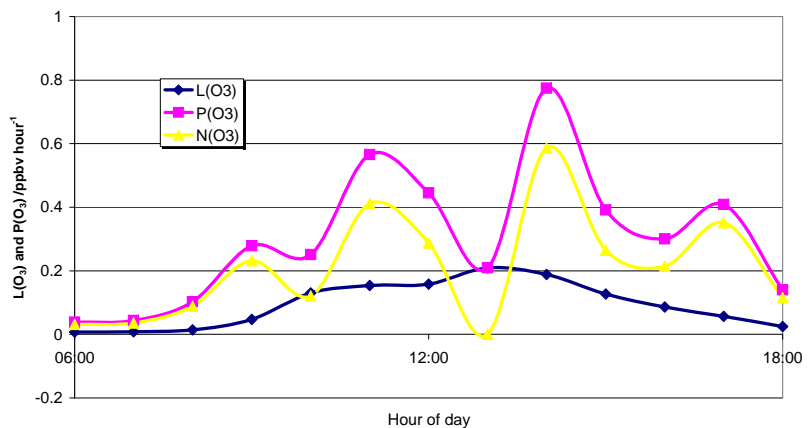

Fig. 15. Case day 8 August: Ozone production, loss and net production.

vary widely from day to day. However, ozone production values show a high degree of variation between days, with midday values varying from 0.1 to $2.5 \mathrm{ppbv} \mathrm{h}^{-1}$. The shift of the maximum ozone loss term towards the afternoon results in the net ozone production being lower in the afternoon than the morning. The rise in $\mathrm{P}\left(\mathrm{O}_{3}\right)$ in the late afternoon caused by high peroxy radical levels leads to an increase in net ozone production at 16:00. This averaged diurnal cycle appears to show overall ozone production but the high $\mathrm{P}\left(\mathrm{O}_{3}\right)$ during the polluted E air-mass sector period of 1-5 August shifts the balance to positive $\mathrm{N}\left(\mathrm{O}_{3}\right)$, despite the many periods of net ozone destruction.

Figure 15 shows $\mathrm{N}\left(\mathrm{O}_{3}\right)$ for 8 August. This was a day where high $\left[\mathrm{NO}_{\mathrm{x}}\right]$ reduced peroxy radical levels and the elevated [NO] led to higher net ozone production than on the days preceding and following it. $\mathrm{A}$ high $\mathrm{NO}_{\mathrm{x}}$ episode in the morning delayed peroxy radical production until around 14:00 (Fig. 7a) and produced high $\mathrm{P}\left(\mathrm{O}_{3}\right)$. At 13:00 $\mathrm{P}\left(\mathrm{O}_{3}\right)$ was low because $\left[\mathrm{NO}_{\mathrm{x}}\right]$ dropped away, and the peroxy radical levels had not yet recovered. The build-up of peroxy radical levels in the afternoon led to a boost in $\mathrm{P}\left(\mathrm{O}_{3}\right)$ and another boost between 17:00 and 18:00 when night-time peroxy radical- forming reactions become important.

Figure 16 shows $\mathrm{N}\left(\mathrm{O}_{3}\right)$ plotted against $\left[\mathrm{NO}_{\mathrm{x}}\right] . \mathrm{N}\left(\mathrm{O}_{3}\right)$ rises sharply with increasing $\left[\mathrm{NO}_{\mathrm{x}}\right]$ until around $1 \mathrm{ppbv}\left[\mathrm{NO}_{\mathrm{x}}\right]$, when the increase in $\mathrm{N}\left(\mathrm{O}_{3}\right)$ levels off. The increase in $\mathrm{N}\left(\mathrm{O}_{3}\right)$, with increasing $\mathrm{NO}_{\mathrm{x}}$, during the SOAPEX 2 campaign at Cape Grim, Tasmania showed very similar characteristics until $\left[\mathrm{NO}_{\mathrm{x}}\right]$ of $0.5 \mathrm{ppbv}$. Investigations of the effect of $\mathrm{NO}_{\mathrm{x}}$ on $\mathrm{N}\left(\mathrm{O}_{3}\right)$ at Mace Head during the spring campaign of EASE 97 showed a much steeper increase in $\mathrm{N}\left(\mathrm{O}_{3}\right)$ at similar $\mathrm{NO}_{\mathrm{x}}$ levels to those seen during NAMBLEX. Table 6 shows the ozone production values for Mace Head - EASE 97 (Salisbury et al., 2002), Cape Grim - SOAPEX 2 (Monks et al., 2005) and NAMBLEX, demonstrating the much higher range during the spring EASE 97 campaign.

Mace Head has experienced a positive trend in background ozone of $0.49 \pm 0.19 \mathrm{ppb}_{\text {year }}{ }^{-1}$ since 1987 (Simmonds et al., 2004), the largest trend being during the winter season. The behaviour of this trend may be attributed to the sensitivity of 
Table 5. Sensitivity of derived $\mathrm{P}\left(\mathrm{O}_{3}\right)$ and $\mathrm{L}\left(\mathrm{O}_{3}\right)$ to $\mathrm{NO}$ from a series of marine boundary layer campaigns.

\begin{tabular}{|c|c|c|}
\hline & $\mathrm{d} \ln \left(\mathrm{P}\left(\mathrm{O}_{3}\right)\right) / \mathrm{d} \ln (\mathrm{NO})$ & $\mathrm{d} \ln \left(\mathrm{L}\left(\mathrm{O}_{3}\right)\right) / \mathrm{d} \ln (\mathrm{NO})$ \\
\hline Cape Grim(SOAPEX $2^{\mathrm{a}}$ ) & $0.90 \pm 0.03$ & $0.06 \pm 0.05$ \\
\hline Mace Head (EASE 97º & $1.10 \pm 0.05$ & $0.27 \pm 0.05$ \\
\hline Weybourne (winter ${ }^{\mathrm{c}}$ ) & $0.92 \pm 0.12$ & $-0.02 \pm 0.14$ \\
\hline Weybourne $\left(\right.$ summer $\left.^{\mathrm{c}}\right)$ & $0.95 \pm 0.02$ & $0.28 \pm 0.05$ \\
\hline Mace Head (NAMBLEX ${ }^{\mathrm{d}}$ ) & $1.0 \pm 0.04$ & $0.32 \pm 0.07$ \\
\hline
\end{tabular}

The uncertainties are given as $1 \sigma$ standard deviations; a) data from Monks et al. (2006); b) data from Salisbury et al. (2002); ${ }^{c)}$ data from Fleming et al. (2006); d) this work.

Table 6. Daily $\mathrm{N}\left(\mathrm{O}_{3}\right)$ campaign average in EASE 97, SOAPEX 2 and NAMBLEX (all in ppbv $\mathrm{h}^{-1}$ ).

\begin{tabular}{|c|c|c|}
\hline Campaign and Season & Season & Mean \\
\hline Mace Head (EASE 96 ${ }^{\mathrm{a}}$ ) & Summer & 0.3 \\
\hline Mace Head (EASE 97a ) & Spring & 1.0 \\
\hline Cape Grim (SOAPEX $2^{b}$ ) & Summer & -0.01 \\
\hline N. Pacific $\left(\right.$ PHOBEA $\left.^{\mathrm{c}}\right)$ & Spring & -0.1 \\
\hline E. Pacific (ORION99d) & Summer & $0.2-3.4$ \\
\hline Mace Head (NAMBLEX ${ }^{\mathrm{e}}$ ) & Summer & 0.11 \\
\hline
\end{tabular}

a) see Salisbury et al. (2002), b) see Monks et al. (2006), ${ }^{\text {c) }}$ Kotchenruther et al. (2001), d) Kanaya et al. (2002), e) this work.

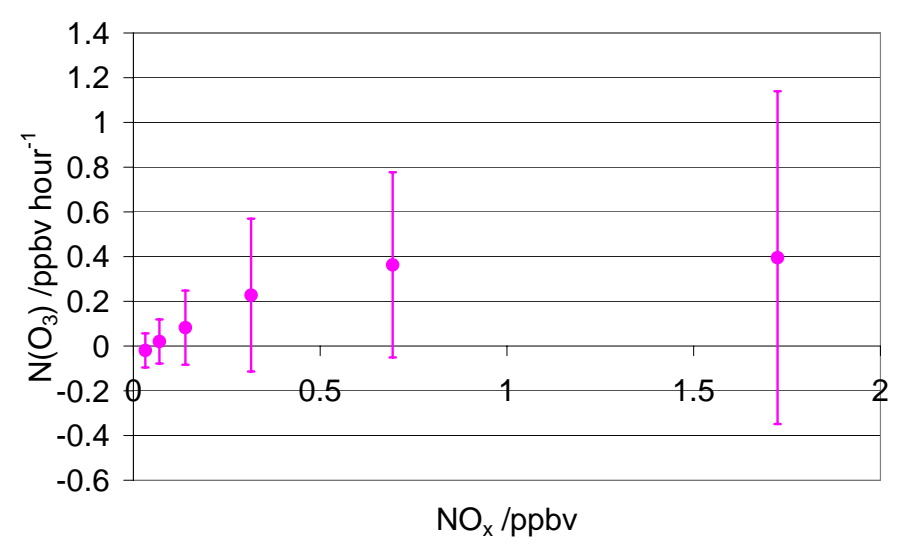

Fig. 16. Net ozone production for daylight hours binned according to $\left[\mathrm{NO}_{\mathrm{x}}\right]$.

the background ozone level to changing European emissions of $\mathrm{NO}_{\mathrm{x}}$ and VOC (Derwent et al., 2003; Monks, 2003). Following the methodology of Stroud et al. (2004) the sensitivity of $\mathrm{P}\left(\mathrm{O}_{3}\right)$ to $\mathrm{NO}$ was calculated as $\mathrm{d} \ln \mathrm{P}\left(\mathrm{O}_{3}\right) / \mathrm{d} \ln (\mathrm{NO})$, as shown in Fig. 17, for a series of marine boundary layer campaigns with differing continental influences. Table 5 summarises the derived sensitivity values of the ozone production term to NO. Both the Mace Head data sets have ozone production with linear sensitivity (i.e. $\operatorname{dln} \mathrm{P}\left(\mathrm{O}_{3}\right) / \mathrm{d} \ln (\mathrm{NO})=1$ )

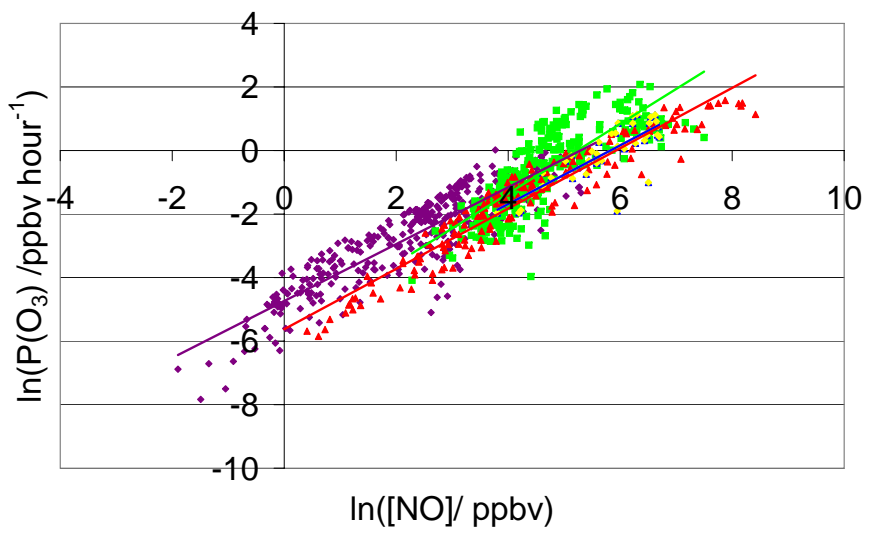

Fig. 17. $\ln \left(\mathrm{P}\left(\mathrm{O}_{3}\right)\right)$ vs. $\ln (\mathrm{NO})$ for Weybourne summer (red) and winter (blue), Mace Head; NAMBLEX (yellow), EASE 97 (green) and Cape Grim; SOAPEX 2 (purple). See Table 5 for campaign details.

to NO as compared to Cape Grim and Weybourne, that have values of around 0.9 . The Mace Head values imply that the ozone production rate is strongly dependent on the [NO]. The equivalent derived values of $\operatorname{dln} \mathrm{L}\left(\mathrm{O}_{3}\right) / \mathrm{d} \ln (\mathrm{NO})$ are also given in Table 5 the bulk of these values range from ca. 0 to 0.3 , unsurprisingly this suggests that $\mathrm{L}\left(\mathrm{O}_{3}\right)$ is generally independent of small changes in [NO]. In tandem, these results imply that the $\mathrm{N}\left(\mathrm{O}_{3}\right)$ will be strongly sensitive in the marine boundary layer to small changes in [NO].

\section{Conclusions}

During NAMBLEX, the Mace Head Atmospheric Research Station received a substantial mix of air-masses from both the Atlantic and from Britain and Ireland. $80 \%$ of the airmasses were from the clean $\mathrm{N}, \mathrm{NW}, \mathrm{W}$ and $\mathrm{SW}$ sectors. The marine air-mass sectors had peroxy radical levels below $10 \mathrm{pptv}$, whereas the other sectors experienced levels above 13 pptv. The higher peroxy radical concentrations in the air-mass sectors with a continental influence were accom- 
panied by over twice as high $\mathrm{NO}_{\mathrm{x}}$ levels and much higher anthropogenic hydrocarbon mixing ratios.

Peroxy radical diurnal cycle maxima were typically shifted towards the afternoon, with daily maximum levels between 10 and $40 \mathrm{pptv}$. MCM modelling of peroxy radical levels provided a good model-measurement comparison, with occasional slight over-estimations by the box model.

Correlations of peroxy radicals with $j\left(\mathrm{O}^{1} \mathrm{D}\right)$ were often disturbed by $\mathrm{NO}_{\mathrm{x}}$ episodes that temporarily lowered peroxy radical levels. No significant reliable linear or square root dependence with $j\left(\mathrm{O}^{1} \mathrm{D}\right)$ was observed to make a clear separation between clean and polluted conditions. Photolysis of compounds other than ozone led to a broader peroxy radical diurnal cycle than would be seen from production via ozone photolysis alone, especially in continentally-influenced airmasses. Correlations with $j(\mathrm{HCHO})$ in the afternoon and a definite shift in the HCHO diurnal cycle towards the afternoon suggests the high potential for HCHO photolysis at this time. A sudden increase in photolysis rates (i.e. a rise in $\left.j\left(\mathrm{O}^{1} \mathrm{D}\right)\right)$ in the early evening was seen to cause a large pulse in peroxy radicals.

Short-term large $\mathrm{NO}_{\mathrm{x}}$ mixing ratios, termed " $\mathrm{NO}_{\mathrm{x}}$ spikes", reaching the site caused a marked drop in peroxy radical levels. Plotting the overall effect of $\mathrm{NO}_{\mathrm{x}}$ on peroxy radical levels during the whole campaign demonstrated a decrease in peroxy radicals with increasing $\mathrm{NO}_{\mathrm{x}}$. A break in the linear decrease around 0.1 and 0.2 ppbv $\mathrm{NO}_{\mathrm{x}}$ was accompanied by an increase in VOCs which led to a short period where peroxy radicals actually increased with $\mathrm{NO}_{\mathrm{x}}$. This VOC influence on peroxy radicals could be thought of as the break between $\mathrm{NO}_{\mathrm{x}}$ - and VOC-limited ozone producing regimes.

Comparisons with FAGE $\mathrm{HO}_{2}$ measurements have shown that $\mathrm{HO}_{2} /\left(\mathrm{HO}_{2}+\sum \mathrm{RO}_{2}\right)$ ratios are dependent on $\left[\mathrm{NO}_{\mathrm{x}}\right]$ and ranged between 0.2 and $0.6 . \mathrm{HO}_{2} /\left(\mathrm{HO}_{2}+\sum \mathrm{RO}_{2}\right)$ ratios increase remarkably linearly with increasing $\mathrm{NO}_{\mathrm{x}}$. The MCM model did not replicate this $\mathrm{NO}_{\mathrm{x}}$-dependence with the model in general over-estimating $\mathrm{HO}_{2} /\left(\mathrm{HO}_{2}+\sum \mathrm{RO}_{2}\right)$ ratios. The addition of halogen oxide chemistry improved the level of agreement. Calculating the expected $\mathrm{HO}_{2} /\left(\mathrm{HO}_{2}+\sum \mathrm{RO}_{2}\right)$ ratios from $\mathrm{OH}$ oxidation reactions of $\mathrm{VOC}, \mathrm{HCHO}$ and $\mathrm{CO}$ did not show any significant $\mathrm{NO}_{\mathrm{x}}$-dependence.

Night-time peroxy radical concentrations rose to as high as 25 pptv in continental air-masses with high $\mathrm{NO}_{\mathrm{x}}$. Sudden $\mathrm{NO}_{3}$ spikes definitely caused an increase in peroxy radicals, but constant higher $\mathrm{NO}_{3}$ levels did not necessarily lead to higher peroxy radical concentrations. Peroxy radical and $\mathrm{NO}_{3}$ mixing ratios were higher in continental compared to marine air-masses. The contribution of ozonealkene and $\mathrm{NO}_{3}$-alkene reactions to peroxy radical formation varies from night to night and there are variations as to which one predominates. At low $\mathrm{NO}_{3}$, ozone-alkene reactions are always predominant

Net photochemical ozone production reached as high as $1.5 \mathrm{ppbv} \mathrm{h}^{-1}$ with the lowest values being negative at $-0.5 \mathrm{ppbv}^{-1}$. Highest net ozone production was observed during high $\mathrm{NO}_{\mathrm{x}}$ periods, demonstrating a clear increase in ozone production at higher $\mathrm{NO}_{\mathrm{x}}$. The ozone production rate is strongly dependent on [NO] having a linear sensitivity $\left(\mathrm{d} \ln \left(\mathrm{P}\left(\mathrm{O}_{3}\right)\right) / \mathrm{d} \ln (\mathrm{NO})=1.0\right)$. The results imply that the $\mathrm{N}\left(\mathrm{O}_{3}\right)$ will be strongly sensitive in the marine boundary layer to small changes in [NO] which has ramifications for changing $\mathrm{NO}_{\mathrm{x}}$ loadings in the European continental boundary layer.

Acknowledgements. This work was conducted under the auspices of the UK-NERC funded project NAMBLEX. The authors would like to thank G. Spain for his logistical support, and also G. Johnson for assistance with $\mathrm{HO}_{2}$ measurements using FAGE.

Edited by: W. T. Sturges

\section{References}

Allan, B. J., Carslaw, N., Coe, H., Burgess, R. A., and Plane, J. M. C.: Observations of the nitrate radical in the marine boundary layer, J. Atmos. Chem, 33, 129-154, 1999.

Allan, B. J., McFiggans, G., Plane, J. M. C., Coe, H., and McFadyen, G. G.: The nitrate radical in the marine boundary layer, J. Geophys. Res., 105, 24 191-24 204, 2000.

Andrés Hernández, M. D., Burkert, A. J., Reichert, L., Stöbener, D., Meyer-Arnek, J., Burrows, J. P., Dickerson, R. R., and Doddridge, B. G.: Marine boundary layer peroxy radical chemistry during the AEROSOLS99 campaign: Measurements and analysis, J. Geophys. Res., 106, 20 833-20 846, 2001.

Ashbourn, S. F. M., Jenkin, M. E., and Clemitshaw, K. C.: Laboratory studies of the response of a peroxy radical chemical amplifier to $\mathrm{HO}_{2}$ and a series of organic peroxy radicals, J. Atmos. Chem., 29, 233-266, 1998.

Ayers, G. P., Penkett, S. A., Gillett, R. W., Bandy, B. J., Galbally, I. E., Meyer, C. P., Elsworth, C. M., Bentley, S. T., and Forgan, B. W.: Evidence for photochemical control of ozone concentrations in unpolluted air, Nature, 360, 446-448, 1992.

Ayers, G. P., Granek, H., and Boers, R: Ozone in the Marine Boundary Layer at Cape Grim: Model Simulation, J. Atmos. Chem., 27, 179-195, 1997.

Ayers, G. P., Gillet, R. W., Granek, H., de Serves, C., and Cox, R. A.: Formaldehyde production in clean marine air, Geophys. Res. Lett., 24, 401-404, 1997.

Biggs, P., Canosa-Mas, C. E., Fracheboud, J.-M., Shallcross, D. E., and Wayne, R. P.: Investigation into the kinetics and mechanism of the reaction of $\mathrm{NO}_{3}$ with $\mathrm{CH}_{3} \mathrm{O}_{2}$ at $298 \mathrm{~K}$ and 2.5 Torr: A potential source of $\mathrm{OH}$ in the nighttime troposphere?, J. Chem. Soc. Faraday Trans., 90, 1205-1210, 1994.

Bitter, M., Ball, S. M., Povey, I. M., Jones, R. L., Saiz-Lopez, A., and Plane, J. M. C.: Measurements of $\mathrm{NO}_{3}, \mathrm{~N}_{2} \mathrm{O}_{5}$, OIO, $\mathrm{I}_{2}$, water vapour and aerosol optical depth by broadband cavity ringdown spectroscopy during the NAMBLEX campaign, Atmos. Chem. Phys., this issue, 2005.

Bloss, C., Wagner, V., Bonzanini, A., Jenkin, M. E., Wirtz, K., Martin-Reviejo, M., and Pilling, M. J.: Evaluation of detailed aromatic mechanisms (MCMv3 and MCMv3.1) against environmental chamber data, Atmos. Chem. Phys., 5, 623-639, 2005a.

Bloss, C., Wagner, V., Jenkin, M. E., Volkamer, R., Bloss, W. J., Lee, J. D., Heard, D. E., Wirtz, K., Martin-Reviejo, M., Rea, 
G., Wenger, J. C., and Pilling, M. J.: Development of a detailed chemical mechanism (MCMv3.1) for the atmospheric oxidation of aromatic hydrocarbons, Atmos. Chem. Phys., 5, 641-664, 2005b.

Bloss, W. J., Gravestock, T. J., Heard, D. E., Ingham, T., Johnson, G. P., and Lee, J. D.: Application of a compact all solid-state laser system to the in-situ detection of atmospheric $\mathrm{OH}, \mathrm{HO}_{2}$, $\mathrm{NO}$ and IO by laser-induced fluorescence, J. Environ. Monit., 5, 21-28, doi:10.1039/b208714f, 2003.

Bloss, W. J., Lee, J. D., Bloss, C., Wirtz, K., Martin-Reviejo, M., Siese, M., Heard, D. E., and Pilling, M. J.: Validation of the calibration of a laser-induced fluorescence instrument for the measurement of $\mathrm{OH}$ radicals in the atmosphere, Atmos. Chem. Phys., 4, 571-583, 2004, mboxhttp://www.atmos-chemphys.net/4/571/2004/.

Bloss, W. J., Lee, J. D., Johnson, G. P., Sommariva, R., Heard, D. E., Saiz-Lopez, A., Plane, J. M. C., McFiggans, G., Coe, H., Flynn, M., Williams, P., Rickard, A. R., and Fleming, Z. L.: Impact of halogen monoxide chemistry upon boundary layer $\mathrm{OH}$ and $\mathrm{HO}_{2}$ concentrations at a coastal site, Geophys. Res. Lett., 32, L06814, 2005c.

Brough, N., Reeves, C. E., Penkett, S. A., Dewey, K., Barjat, H., Monks, P. S., Ziereis, H., Stock, P., Huntrieser, H., and Schlager, H.: Intercomparison of aircraft instruments on board the C-130 and Falcon 20 over Southern Germany during EXPORT 2000, Atmos. Chem. Phys., 3, 2127-2138, 2003, mboxhttp://www.atmos-chem-phys.net/3/2127/2003/.

Cantrell, C. A., Stedman, D. H., and Wendel, G. J.,: Measurement of atmospheric peroxy radicals by chemical amplification, Anal. Chem., 56, 1496-1502, 1984.

Cantrell, C. A., Shetter, R. E., Gilpin, T. M., Calvert, J. G., Eisele F. L., and Tanner, D. J.: Peroxy radical concentrations measured and calculated from trace-gas measurements in the Mauna Loa Observatory Photochemistry Experiment 2, J. Geophys. Res., 101, $14653-14644,1996 a$.

Cantrell, C. A., Shetter, R. E., and Calvert, J. G.: Dual-inlet Chemical amplifier for atmospheric peroxy radical measurements, Anal. Chem., 58, 4194-4199, 1996b.

Cantrell, C. A., Shetter, R. E., Calvert, J. G., Eisele F. L., Williams, E., Baumann, K., Brune, W. H., Stevens P. S., and Mather, J. H.: Peroxy radicals from photostationary-state deviations and steady-state calculations during the Tropospheric OH Photochemistry Experiment at Idaho Hill, Colorado, 1993, J. Geophys. Res., 102, 6369-6378, 1997.

Cardenas, L. M., Brassington, D. J., Allan, B. J., Coe, H., Alicke, B., Platt, U., Wilson, K. M., Plane, J. M. C., and Penkett, S. A.: Intercomparison of formaldehyde measurements in clean and polluted atmospheres, J. Atmos. Chem., 37, 53-80, 2000.

Carpenter, L. J., Monks, P. S., Bandy, B. J., and Penkett, S. A.: A study of peroxy radicals and ozone photochemistry at coastal sites in the northern and southern hemispheres, J. Geophys. Res., 102, 25 417-25 427, 1997.

Carslaw, N., Carpenter, L. J., Plane, J. M. C., Allan, B. J., Burgess, R. A., Clemitshaw, K. C., Coe, H., and Penkett, S. A.: Simultaneous observations of nitrate and peroxy radicals in the marine boundary layer, 1 . Model construction and comparison with field measurements, J. Geophys. Res., 102, 18 917-18 933, 1997.

Carslaw, N., Creasey, D. J., Heard, D. E., Lewis, A. C., McQuaid, J. B., Pilling, M. J., Monks, P. S., Bandy, B. J., and Penkett, S. A.:
Modelling $\mathrm{OH}, \mathrm{HO}_{2}$ and $\mathrm{RO}_{2}$ radicals in the marine boundary layer 1. Model construction and comparison with field measurements, J. Geophys. Res., 104, 30 241-30 255, 1999.

Carslaw, N., Creasey, D. J., Heard, D. E., Jacobs, P. J., Lee, J. D., Lewis, A. C., McQuaid, J. B., Pilling, M. J., Bauguitte, S., Penkett, S. A., Monks, P. S., and Salisbury, G.: Eastern Atlantic Spring Experiment 1997 (EASE97) - 2. Comparisons of model concentrations of $\mathrm{OH}, \mathrm{HO}_{2}$, and $\mathrm{RO}_{2}$ with measurements, J. Geophys. Res., 107, 4190, doi:10.1029/2001JD001568, 2002.

Carslaw, N., Bell, N., Lewis, J. B., McQuaid, J. B., and Pilling, M. J.: A detailed study of isoprene chemistry during the EASE 96 campaign, Atmos. Environ., 34, 2827-2836, 2000.

Clemitshaw, K. C., Carpenter, L. J., Penkett, S. A., and Jenkin, M. E.: A calibrated peroxy radical chemical amplifier (PERCA) for ground-based measurements in the troposphere, J. Geophys. Res., 102, 25 405-25 416, 1997.

Creasey, D. J., Halford-Maw, P. A., Heard, D. E., Pilling, M. J., and Whitaker, B. J.: Implementation and initial deployment of a field instrument for measurement of $\mathrm{OH}$ and $\mathrm{HO}_{2}$ in the troposphere by laser-induced fluorescence, J. Chem. Soc., Faraday Trans., 93(16), 2907-2913, 1997.

Creasey, D. J., Heard, D. E., and Lee, J. D.: The Eastern Atlantic Spring Experiment (EASE) 1997: (1) $\mathrm{OH}$ and $\mathrm{HO}_{2}$ radical measurements at Mace Head, Eire, J. Geophys. Res., 107(D10), 892, doi:10.1029/2001JD000892, 2002.

Creasey, D. J., Evans, G. E., Heard, D. E., and Lee, J. D.: Measurements of $\mathrm{OH}$ and $\mathrm{HO}_{2}$ concentrations in the Southern Ocean marine boundary layer, J. Geophys. Res., 108, doi:10.1029/2002JD003206, 2003.

Derwent, R. G., Simmonds, P. G., and Collins, W. J.: Ozone and carbon monoxide measurements at a remote maritime location, Mace Head, Ireland from 1990 to 1992, Atmos. Environ., 28, 2623-2637, 1994.

Derwent, R. G., Simmonds, P. G., Seuring, S., and Dimmer, C.: Observation and interpretation of the seasonal cycles in the surface concentrations of ozone and carbon monoxide at Mace Head, Ireland from 1990 to 1994, Atmos. Env., 32, 145-157, 1998.

Derwent, R. G., Jenkin, M. E., Saunders, S. M., Pilling, M. J., Simmonds, P. G., Passant, N. R., Dollard, G. J., Dumitrean, P., and Kent, A.: Photochemical ozone formation in north west Europe and its control, Atmos. Environ., 37, 1983-1991, 2003.

Edwards, G. D. and Monks, P. S.: Performance of a single monochromator diode array spectrradiometer for the determination of actinic flux and atmospheric frequencies, J. Geophys. Res., 108, 8546-8558, 2003.

Fleming, Z. L.: The measurement of peroxy radicals in the marine boundary layer using the PERCA technique, $\mathrm{PhD}$ thesis, University of Leicester, 2006.

Geyer, A., Bachmann, K., Hofzumahaus, A., Holland, F., Konrad, S., Klupfel, T., Patz, H. W., Perner, D., Mihelcic, D., Schafer, H. J., Volz-Thomas, A., and Platt, U.: Nightime formation of peroxy and hydroxy radicals during the BERLIOZ campaign: observations and modelling studies, J. Geophys. Res., 108, doi:10.1029/2001JD0006569, 2003.

Green, T. J., Brough, N., Reeves, C. E., Edwards, G. D., Monks, P. S., and Penkett, S. A.: Airborne measurements of peroxy radicals using the PERCA technique, J. Environ. Monitoring, 5, 75-83, 2003.

Green, T. J., Reeves, C. E., Fleming, Z. L., Brough, N., Rickard, 
A. R., Bandy, B. J., Monks, P. S., and Penkett, S. A.: An improved dual channel PERCA for atmospheric measurements of peroxy radicals, J. Environ. Monitoring, 8, 530-536, doi:10.1039/b514630e, 2006.

Grossman, D., Moortgat, G. K., Kibler, M., Schlomski, S., Bächmann, K., Alicke, B., Geyer, A., Platt, U., Hammer, M.-U., Vogel, B., Mihelcic, D., Hofzumahaus, A., Holland, F., and Volz-Thomas, A.: Hydrogen peroxide, organic peroxides, carbonyl compounds and organic acids measured at Pabstthum during BERLIOZ, J. Geophys. Res., 108, 8250, doi:10.1029/2001JD001096, 2003.

Heard, D. E., Read, K. A., Al-Haider, S., Bloss, W. J., Johnson, G. P., Pilling, M. J., Rickard, A. R., Seakins, P. W., Smith, S. C., Sommariva, R., Stanton, J. C., Still, T., Brooks, B., Jackson, A. V., McQuaid, J. B., Morgan, R., Smith, M. H., Carslaw, N., Hamilton, J., Hopkins, J. R., Lee, J. D., Lewis, A. C., Purvis, R. M., Wevill, D. J., Brough, N., Green, T., Mills, G., Penkett, S. A., Plane, J. M. C., Saiz-Lopez, A., Worton, D., Monks, P. S., Fleming, Z., Alfarra, M., Allan, J. D., Bower, K., Coe, H., Cubison, M., Flynn, M., McFiggans, G., Gallagher, M., Norton, E. G., Shillito, J., Topping, D., Vaughan, G., Williams, P., Bitter, M., Ball, S. M., Jones, R. L., Povey, I. M., O’Doherty, S., Noone, C., Simmonds, P. G., Allen, A., Kinnersley, R., Beddows, D., Dall'Osto, M., Harrison, R. M., Donovan, R., Heal, M., Methven, J., Jennings, G., and Spain, G.: The North Atlantic Marine Boundary Layer Experiment (NAMBLEX). Overview of the campaign held at Mace Head, Ireland, in summer 2002, Atmos. Chem. Phys. Discuss., 5, 12 177-12 254, 2005.

Heikes, B., Lee, M., Jacob, D., Talbot, R., Bradshaw, J., Singh, H., Blake, D., Anderson, B., Fuelberg, H., and Thompson, A.: Ozone, hydroperoxides, oxides of nitrogen, and hydrocarbon budgets in the marine boundary layer over the South Atlantic, J. Geophys. Res., 101, 24 221-24 234, 1996.

Holland, F., Hofzumahaus, A., Schäfer, J., Kraus, A., and Pätz, H.W.: Measurements of $\mathrm{OH}$ and $\mathrm{HO}_{2}$ radical concentrations and photolysis frequencies during BERLIOZ, J. Geophys. Res., 108, 8246-8267, 2003.

Hopkins, J. R., Lewis, A. C., and Read, K. A.: A Two Column Method for Long-term Monitoring of Non-Methane Hydrocarbons (NMHCs) and Oxygenated Volatile Organic Compounds, J. Environ. Monit., 5, 8-13, 2003a.

Hopkins, J. R., Still, T., Al-Haider, S., Fisher, I. R., Lewis, A. C., and Seakins, P. W.: A simplified apparatus for ambient formaldehyde detection via GC-PHID, Atmos. Env., 37, 25572565, 2003b.

Jenkin, M. E., Saunders, S. M., and Pilling, M. J.: The tropospheric degradation of volatile organic compounds: A protocol for mechanism development, Atmos. Environ., 31, 81-104, 1997.

Jenkin, M. E, Saunders, S. M., Wagner, V., and Pilling, M.: Protocol for the development of the Master Chemical Mechanism, MCM v3 (Part A): tropospheric degradation of non-aromatic volatile organic compounds (Part B): tropospheric degradation of aromatic volatile organic compounds, Atmos. Chem. Phys., 3, 161193, 2003, mboxhttp://www.atmos-chem-phys.net/3/161/2003/.

$\mathrm{Hu}$, J. and Stedman, D. H.: Atmospheric $\mathrm{RO}_{\mathrm{x}}$ radicals at an urban site; Comparison to a simple theoretical model, Environ. Sci. Technol., 29, 1655-1659, 1995.

Hunter, M. C., Bartle, K. D., Seakins, P. W., and Lewis, A. C.: Direct measurement of atmospheric formaldehyde using gas chromatography-pulsed discharge ionisation detection, Anal Commun., 36, 101-104, 1999.

Kanaya, Y., Matsumoto, J., and Akimoto, H.: Photochemical ozone production at a subtropical island of Okinawa, Japan: Implications from simultaneous observations of $\mathrm{HO}_{2}$ radical and $\mathrm{NOx}$, J. Geophys. Res., 107, 4368, doi:10.1029/2001JD000858, 2002.

Kotchenruther, R. A., Jaffe, D. A., and Jaeglé, L.: Ozone photochemistry and the role of peroxyacetlynitrate in the springtime Pacific troposphere: Results from the Photochemical Ozone Budget of the Eastern North Pacific Atmosphere (PHOBEA) campaign, J. Geophys. Res., 106, 28 731-28 742, 2001.

Kraus, A. and Hofzumahaus, A.: Field measurements of atmospheric photolysis frequencies for $\mathrm{O}_{3}, \mathrm{NO}_{2}, \mathrm{HCHO}, \mathrm{CH}_{3} \mathrm{CHO}$, $\mathrm{H}_{2} \mathrm{O}_{2}$ and HONO by UV spectroradiometry, J. Atmos. Chem., 31, 161-180, 1998.

Lawson, D. R., Bierman, H. W., Tuazon, E. C., Winer, A. M., Mackay, G. I., Schiff, H. I., Kok, G. L., Dasgupta, P. K., and Fung, K.: Formaldehyde measurements methods evaluation and ambient concentrations during the carbonaceous species comparison study, Aerosol Sci. Technol., 12, 64-76, 1990.

Lewis, A. C., Bartle, K. D., McQuaid, J. B., Pilling, M. J., Seakins, P. W., and Ridgeon, P.: Atmospheric monitoring of volatile organic compounds using programmed temperature vaporisation injection, J. High Res. Chromat., 19, 686-690, 1996.

Lewis, A. C., Hopkins, J. R., Read, K. A., Carpenter, L. J., Pilling, M. J., and Stanton, J.: Sources and sinks of acetaldehyde, acetone and methanol in north Atlantic marine boundary layer air, Atmos. Chem. Phys., 5, 1963-1974, 2005, mboxhttp://www.atmoschem-phys.net/5/1963/2005/.

Mather, J. H., Stevens, P. S., and Brune, W. H.: $\mathrm{OH}$ and $\mathrm{HO}_{2}$ measurements using laser-induced fluorescence, J. Geophys. Res., 102(D5), 6427-6436, doi:10.1029/96JD01702, 1997.

Metcalfe, S. E., Whyatt, J. D., Derwent, R. G., and O'Donoghue, M.: ATMOS env The regional distribution of ozone across the British Isles and its response to control strategies, Atmos. Environ., 36, 4045-4055, 2002.

Mihelcic, D., Klemp, D., Müsgen, P., Pätz, H. W., Kley, D., and Volz-Thomas, A.: Simultaneous measurements of peroxy and nitrate radicals at Schauinsland, J. Atmos. Chem., 16, 313-335, 1993.

Mihelcic, D., Holland, F., Hofzumahaus, A., Hoppe, L., Konrad, S., Müsgen, P., Pätz, H.-W., Schäfer, H.-J., Schmitz, T., VolzThomas, A., Bächmann, K., Schlonski, S., Platt, U., Geyer, A., Alicke, B., and Moorgat, G. K.: Peroxy radicals during BERLIOZ at Pabstthum: Measurements, radical budgets and ozone production, J. Geophys. Res., 108, 8254-8268, 2003.

Mihele, C. M. and Hastie, D. R.: The sensitivity of the amplifier to ambient water vapour, Geophys. Res. Lett., 25, 1911-1913, 1998.

Mihele, C. M., Mozurkewich, M., and Hastie, D. R.: Radical loss in a chain reaction of $\mathrm{CO}$ and NO in the presence of water: Implications for the radical amplifier and atmospheric chemistry, Int. J. Chem. Kin., 31, 145-152, 1999.

Monks, P. S., Carpenter, L. J., and Penkett, S. A.: Night-time peroxy radical chemistry in the remote marine boundary layer over the Southern ocean, Geophys. Res. Lett., 23, 535-538, 1996.

Monks, P. S., Carpenter, L. J., Penkett, S. A., Ayers, G. P., Gillett, R. W., Galbally, I. E., and Meyer, C. P.: Fundamental ozone photochemistry in the remote boundary layer: The SOAPEX experi- 
ment, measurement and theory, Atmos. Environ., 32, 3647-3664, 1998.

Monks, P. S., Holland, G., Salisbury, G., Penkett, S. A., and Ayers, G. P.: A seasonal comparison of ozone photochemistry in the remote marine boundary layer, Atmos. Env., 34, 2547-2561, 2000.

Monks, P. S.: Chapter 6, Tropospheric photochemistry, in: "Handbook of Atmospheric science: Principle and Application", edited by: Hewitt, C. N., and Jackson, A. V., Blackwell Publishing, Oxford, 2003.

Monks, P. S.: TROTREP Synthesis and Integration Report, Report to the EU FPV Energy, Environment and Sustainable Development Program, European Union, 2003.

Monks, P. S., Rickard, A. R., and Hall, S. L.: Attenuation of spectral actinic flux and photolysis frequencies at the surface through homogeneous cloud fields, J. Geophys. Res., 109, doi:10.1029/2003JD004076, 2004.

Monks, P. S.: Gas-phase radical chemistry in the troposphere, Chem. Soc. Rev., 34, 376-395, 2005.

Morgan, R. B. and Jackson, A. V.: Measurements of gas-phase hydrogen peroxide and methyl hydroperoxide in the coastal environment during the PARFORCE project, J. Geophys. Res, 107(D19), 8109, doi:10.1029/2000JD000257, 2002.

Morgan, R. B.: Field studies of atmospheric peroxides and the development of sampling methods, $\mathrm{PhD}$ thesis, University of Leeds, 2004.

Norton, E. G., Vaughan, G., Methven, J., Coe, H., Brooks, B., Gallagher, M., and Longley, I.: Boundary layer structure and decoupling from synoptic scale flow during NAMBLEX, Atmos. Chem. Phys. Discuss., 5, 3191-3223, 2005, mboxhttp://www.atmos-chem-phys-discuss.net/5/3191/2005/.

Penkett, S. A., Blake, N. J., Lightman, P., Marsh, A. R. W., Anwyl, P., and Butcher, G.: The seasonal variation of non-methane hydrocarbons in the free troposphere over the North Atlantic Ocean: possible evidence for extensive reaction of hydrocarbons with the nitrate radical, J. Geophys. Res., 98, 2865-2885, 1993.

Penkett, S. A., Monks, P. S., Carpenter, L. J., and Clemitshaw, K. C.: Relationships between ozone photolysis rates and peroxy radical concentrations in clean air over the Southern Ocean, J. Geophys. Res., 102, 12 805-12 817, 1997.

Penkett, S. A., Clemitshaw, K. C., Savage, N. H., Burgess, R. A., Cardenas, L. M., Carpenter, L. J., McFadyden, G. G., and Cape, J. N.: Studies of oxidant production at the Weybourne Atmospheric observatory in summer and winter conditions, J. Atmos. Chem., 33, 111-128, 1999.

Platt, U., LeBras, G., Poulet, G., Burrows, J. P., and Moorgat, G.: Peroxy radicals from nighttime reaction of $\mathrm{NO}_{3}$ with organic compounds, Nature, 348, 147-149, 1990.

Reichert, L., Hernandez, M. D. A., Stobener, D., Burkert, J., and Burrows, J. P.: Investigation of the effect of water complexes in the determination of peroxy radical ambient concentrations: Implications for the atmosphere, J. Geophys. Res., 108, 4017, doi:10.1029/2002JD002152, 2003.

Rickard, A. R., Johnson, D., McGill, C. D., and Marston, G.: OH yields in the gas-phase reactions of ozone with alkenes, J. Phys. Chem., 103, 7656-7664, 1999.

Rickard, A. R., Salisbury, G., Monks, P. S., Lewis, A. C., Bauguitte, S., Bandy, B. J., Clemitshaw, K. C., and Penkett, S. A.: Comparison of measured ozone production efficiencies in the marine boundary layer at two European coastal sites under different pollution regimes, J. Atmos. Chem., 43, 107-134, 2002.

Saiz-Lopez, A., Shillito, J. A., Coe, H., and Plane, J. M. C.: Measurements and modelling of $\mathrm{I}_{2}, \mathrm{IO}, \mathrm{OIO}, \mathrm{BrO}$ and $\mathrm{NO}_{3}$ in the mid-latitude marine boundary layer, Atmos. Chem. Phys., 6, 1513-1528 2006.

Salisbury, G., Rickard, A. R., Monks, P. S., Allan, B. J., Bauguitte, S., Penkett, S. A., Carslaw, N., Lewis, A. C., Creasy, D. J., Heard, D. E., Jacobs, P. J., and Lee, J. D.: Production of peroxy radicals at night via reactions of ozone and the nitrate radical in the marine boundary layer, J. Geophys. Res., 106, 12 669-12 687, 2001.

Salisbury, G., Monks, P. S., Bauguitte, S., Bandy, B. J., and Penkett, S. A.: A seasonal comparison of the ozone photochemistry in clean and polluted air masses at Mace Head, Ireland, J. Atmos. Chem., 41, 163-187, 2002.

Saunders, S. M., Jenkin, M. E., Derwen, R. G., and Pilling, M. J.: Protocol for the development of the Master Chemical Mechanism, MCM v3 (Part A): tropospheric degradation of non-aromatic volatile organic compounds, Atmos. Chem. Phys., 3, 161-180, 2003, mboxhttp://www.atmos-chemphys.net/3/161/2003/.

Sillman, S.: The use of $\mathrm{NO}_{\mathrm{y}}, \mathrm{H}_{2} \mathrm{O}_{2}$ and $\mathrm{HNO}_{3}$ as indicators for ozone-hydrocarbon sensitivity in urban locations, J. Geophys. Res., 100(D7), 14 175-14 188, 1995.

Simmonds, P. G., Derwent, R. G., Manning, A. L., and Spain, G.: Significant growth in surface ozone at Mace Head, Ireland, 1987-2003, Atmos. Environ., 38, 4679-4778, 2004.

Smith, S., Lee, J. D., Bloss, W. J., Johnson, G. P., Ingham, T., and Heard, D. E.: Concentrations of $\mathrm{OH}$ and $\mathrm{HO}_{2}$ radicals during NAMBLEX: Measurement and steady-state analysis, Atmos. Chem. Phys., 6, 1435-1453, 2006, mboxhttp://www.atmoschem-phys.net/6/1435/2006/.

Sommariva, R. C.: Understanding field measurements through a Master Chemical Mechanism, $\mathrm{PhD}$ thesis, University of Leeds, 2006.

Sommariva, R., Bloss, W. J., Brough, N., Carslaw, N., Flynn, M., Haggerstone, A.-L., Heard, D. E., Hopkins, J. R., Lee, J. D., Lewis, A. C., McFiggans, G., Monks, P. S., Penkett, S. A., Pilling, M. J., Plane, J. M. C., Read, K. A., Richard, A. R., Saiz-Lopez, A., and Williams, P. I.: $\mathrm{OH}$ and $\mathrm{HO}_{2}$ chemistry during NAMBLEX: roles of oxygenates, halogen oxides and heterogeneous uptake, Atmos. Chem. Phys., 6, 1135-1153, 2006, mboxhttp://www.atmos-chem-phys.net/6/1135/2006/.

Sommariva, R., Ball, S. M., Bitter, M., Bloss, W. J., Fleming, Z. L., Heard, D. E., Jones, R. L., Lee, J. D., Monks, P. S., Pilling, M. J., Plane, J. M. C., and Saiz-Lopez, A.: Night-time radical chemistry during the NAMBLEX campaign, Atmos. Chem. Phys. Discuss., 2006b.

Still, T. J., Al-Haider, S., Seakins, P. W., Sommariva, R., Stanton, J. C., Mills, G., and Penkett, S. A.: Ambient formaldehyde measurements made at a remote marine boundary layer site during the NAMBLEX campaign - a comparison of data from chromatographic and modified Hantzsch techniques, Atmos. Chem. Phys. Discuss., 5, 12 531-12 567, 2005.

Starn, T. K., Shepson, P. B., Bertman, S. B., White, J. S., Splawn, B. G., Riemer, D. D., Zika, R. G., and Olszyna, K.: Observations of isoprene chemistry and its role in ozone production at a semirural site during the 1995 Southern Oxidants Study, J. Geophys. Res., 103(D17), 22 425-22 436, doi:10.1029/98JD01279, 1998. 
Stroud, C., Madronich, S., Atlas, E., Cantrell, C., Fried, A., Wert, B., Ridley, B., Eisele, F., Mauldin, L., Shetter, R., Lefer, B., Flocke, F., Weinheimer, A., Coffey, M., Heikes, B., Talbot, R., and Bealer, D.: Photochemistry in the Arctic Free Troposphere: Ozone Budget and Its Dependence on Nitrogen Oxides and the Production Rate of Free Radical, J. Atmos. Chem., 47, 107-138, 2004.

Wayne, R. P., Barnes, I., Biggs, P., Burrows, J. P., Canosa-Mas, C. E., Hjorth, J. G., LeBras, G., Moortgat, K., Perner, D., Poulet, G., Restelli, G., and Sidebottom, H.: The nitrate radical: Physics, chemistry and the environment, Atmos. Environ., 25, 1-206, 1991.
Zanis, P., Monks, P. S., Schuepbach, E., and Penkett, S. A.: On the relationship of $\mathrm{HO}_{2}+\mathrm{RO}_{2}$ with $j\left(\mathrm{O}^{1} \mathrm{D}\right)$ during the Free Tropospheric Experiment (FREETEX '96) at the Jungfraujoch Observatory ( $3580 \mathrm{~m}$ above sea level) in the Swiss Alps, J. Geophys. Res., 104, 26 913-26 925, 1999. 